\title{
Glycogen synthase kinase-3 is an intermediate modulator of serotonin neurotransmission
}

\author{
Abigail M. Polter and Xiaohua Li* \\ Department of Psychiatry and Behavioral Neurobiology, University of Alabama at Birmingham, Birmingham, AL, USA
}

Edited by:

Jean-Martin Beaulieu, Université

Laval, Canada

\section{Reviewed by:}

Raul Gainetdinov, Italian Institute of

Technology, Italy

Peter S. Klein, University of

Pennsylvania, USA

${ }^{*}$ Correspondence:

Xiaohua Li, Department of Psychiatry and Behavioral Neurobiology,

University of Alabama at Birmingham, 17207 th Avenue South, Sparks

Center, 1075, Birmingham, AL 35294, USA.

e-mail:xili@uab.edu
Serotonin is a neurotransmitter with broad functions in brain development, neuronal activity, and behaviors; and serotonin is the prominent drug target in several major neuropsychiatric diseases. The multiple actions of serotonin are mediated by diverse serotonin receptor subtypes and associated signaling pathways. However, the key signaling components that mediate specific function of serotonin neurotransmission have not been fully identified. This review will provide evidence from biochemical, pharmacological, and animal behavioral studies showing that serotonin regulates the activation states of brain glycogen synthase kinase-3 (GSK3) via type 1 and type 2 serotonin receptors. In return, GSK3 directly interacts with serotonin receptors in a highly selective manner, with a prominent effect on modulating serotonin 1B receptor activity. Therefore, GSK3 acts as an intermediate modulator in the serotonin neurotransmission system, and balanced GSK3 activity is essential for serotonin-regulated brain function and behaviors. Particularly important, several classes of serotonin-modulating drugs, such as antidepressants and atypical antipsychotics, regulate GSK3 by inhibiting its activity in brain, which reinforces the importance of GSK3 as a potential therapeutic target in neuropsychiatric diseases associated with abnormal serotonin function.

Keywords: serotonin, GSK3, 5-HT1A, 5-HT1B, 5-HT2A, antidepressants

\section{SEROTONIN NEUROTRANSMISSION SEROTONIN}

Serotonin (5-hydroxytryptamine, 5-HT) is a monoaminergic neurotransmitter that is synthesized from the amino acid tryptophan. Serotonergic neurons arise from the raphe nucleus of the brain stem, and they project upward to most areas of the brain and downward to peripheral nerve terminals. Upon release, 5-HT in the synapse is recycled by reuptake through the 5-HT transporter (5-HTT) and is catabolized by monoamine oxidase (MAO). There are at least 7 families and 14 subtypes of 5-HT receptors that are classified by their sequence homology and associated type of Gproteins and signal transduction pathways (Hoyer and Martin, 1997; Bockaert et al., 2006; Table 1). Among these 5-HT receptors, the type 1 (5-HT1) and the type 2 (5-HT2) receptors are the most studied, with rich literatures showing their roles in brain function and diseases (Hannon and Hoyer, 2008).

\section{SEROTONIN TYPE 1A (5-HT1A) RECEPTORS}

5-HT1A receptors are the prototypical 5-HT1 receptors. In addition to coupling to the inhibitory G-protein (Gi) that inhibits adenylyl cyclase, decreases cyclic AMP (cAMP) production, and inactivates protein kinase A (PKA; De Vivo and Maayani, 1986), studies in neurons reveal that 5-HT1A receptors also regulate other protein kinases, such as growth factor-associated Akt and extracellular signal-regulated kinases (Erk; Cowen et al., 1996, 2005). 5-HT1A receptors are widely distributed in major brain areas including the dorsal raphe nucleus, cerebral cortex, hippocampus, striatum, and nucleus accumbens (Varnas et al., 2004). In 5-HT neurons, 5-HT1A autoreceptors are located in the cell bodies and somatodendrites, and activation of these receptors reduces neuron firing and suppresses 5-HT release (Riad et al., 2000). In nonserotonergic neurons, 5-HT1A heteroreceptors are found in both pre- and post-synaptic locations (Hoyer et al., 2002). Depending on the location and associated neurons, activation of 5-HT1A heteroreceptors modulates neurotransmission of glutamate, GABA, norepinephrine, and acetylcholine (Fink and Gothert, 2007), generally causing inhibition of long-term potentiation (Edagawa et al., 1998; Tachibana et al., 2004), increased axonal and dendritic branching (Yan et al., 1997), and postnatal neurogenesis (Banasr et al., 2004). 5-HT1A receptors mediate many behavioral effects of 5-HT, particularly those related to mood and anxiety (Kennett et al., 1987; Parks et al., 1998).

\section{SEROTONIN TYPE 1B (5-HT1B) RECEPTORS}

The rodent 5-HT1B receptors and its human homolog 5-HT1D receptors share high protein sequence homology and signal transduction processes with 5-HT1A receptors, and 5-HT1B receptors also act as both autoreceptors and heteroreceptors in the brain (Bouhelal et al., 1988; Hoyer and Martin, 1997; Leone et al., 2000; Bockaert et al., 2006). Different from 5-HT1A autoreceptors, 5HT1B autoreceptors are primarily located on the 5-HT neuron axon terminals that extend to other brain regions. Upon activation, 5-HT1B autoreceptors cause a strong feedback inhibition of 5-HT release (Riad et al., 2000). 5-HT1B receptors also act as heteroreceptors in several brain regions to control release of other neurotransmitters (Sari, 2004). Both 5-HT1B receptor agonists and antagonists may have antidepressant effects; blocking autoreceptors increases extracellular 5-HT which enhances the effect of 
Table 1 | Serotonin receptors.

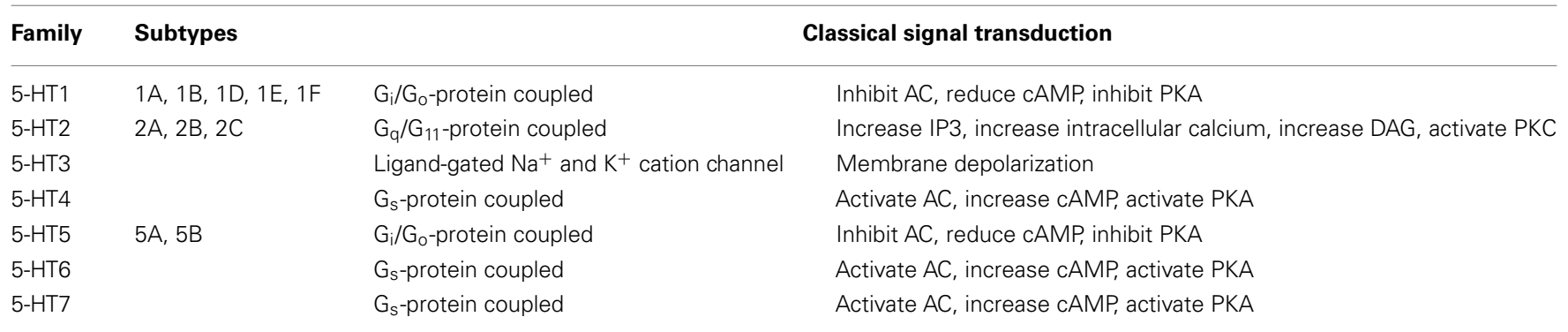

serotonin-reuptake inhibitors (Dawson et al., 2006), whereas activation of heteroreceptors contributes to an antidepressant effect, potentially through their effects on dopaminergic neurotransmission (Chenu et al., 2008). Recently, 5-HT1B receptors have been found to interact with an intracellular adaptor protein p11 (Svenningsson et al., 2006), which regulates 5-HT1BR activity and stability, and deletion of which causes depression-like behaviors in animals (Svenningsson and Greengard, 2007).

\section{SEROTONIN TYPE 2A (5-HT2A) RECEPTORS}

5-HT2A receptors are the prototypical type $25-\mathrm{HT}$ receptors that couple to $\mathrm{Gq}$ protein to activate phospholipase $\mathrm{C}$ (PLC) and its down-stream targets such as protein kinase C (PKC; Conn and Sanders-Bush, 1984; Roth et al., 1986; Takuwa et al., 1989). 5HT2A receptors have also been reported to activate Akt and Erk (Watts, 1998; Johnson-Farley et al., 2005; Zhong et al., 2008), although the receptor-coupling mechanism of this regulation is not completely understood. 5-HT2A receptors also couple to the intracellular scaffolding protein $\beta$-arrestin 2 , which may have unique functions to initiate desensitization of 5-HT2A receptors and to direct ligand-selective signal transduction processes (Schmid et al., 2008; Schmid and Bohn, 2010). 5-HT2A receptors are expressed throughout the brain, most prominently in the cerebral cortex, striatum, and hippocampus (Bockaert et al., 2006), where they are located on soma, dendrites, and axons of pyramidal neurons, interneurons, and monoaminergic neurons (Jakab and Goldman-Rakic, 1998; Cornea-Hebert et al., 1999; Hoyer et al., 2002; Miner et al., 2003). Activation of 5-HT2A receptors modulates levels of other neurotransmitters, such as causing inhibitory control over dopamine release (Schmidt and Fadayel, 1995). In many studies, 5-HT2A receptors are found to counteract the physiological and behavioral effects of 5-HT1A receptors (Marek et al., 2003). For example, Yuen et al. (2008) reported that activation of 5-HT2A/C receptors in prefrontal cortical neurons significantly attenuates the effect of 5-HT1A receptors on NMDA currents and microtubule depolymerization. 5-HT2A receptors have a different behavioral profile as 5-HT1A receptors. Most notably, a group of 5-HT2A receptor agonists are hallucinogens (Nichols, 2004), but 5-HT2A receptors also have significant effects in regulating other neuropsychiatric behaviors, such as mood, cognition, and sleep (Landolt and Wehrle, 2009).

\section{THERAPEUTIC IMPLICATIONS OF 5-HT MODULATORS}

For decades, modulation of 5-HT neurotransmission has been the primary pharmacological target for the treatment of major neuropsychiatric diseases, particularly depression and anxiety. The monoamine oxidase inhibitors (MAOI) enhance 5-HT neurotransmission by blocking 5-HT metabolism (Youdim and Bakhle, 2006), while tricyclic antidepressants (TCA; Klerman and Cole, 1965), serotonin-selective reuptake inhibitors (SSRI), and serotonin-norepinephrine reuptake inhibitors (SNRI) all enhance synaptic 5-HT action by blocking reuptake of 5-HT. Global enhancement of serotonin neurotransmission may activate all subtypes of serotonin receptors in brain, while each 5-HT receptor subtype has different and specific functions in defined brain regions. Activation of 5-HT1A receptors is thought to contribute to the effect of antidepressants in regulating mood and anxiety (Parks et al., 1998; Ramboz et al., 1998; Leonardo and Hen, 2008; Akimova et al., 2009; Savitz et al., 2009; Polter and Li, 2010; Price and Drevets, 2010), whereas acute activation-induced down-regulation of 5HT1A autoreceptors may be necessary for the antidepressant and anxiolytic effects during long-term 5-HT reuptake inhibitor treatment (Blier and Ward, 2003; Albert and Lemonde, 2004). The specific roles of other 5-HT receptor subtype in the antidepressant action remain to be largely unknown.

In addition to enhancing 5-HT neurotransmission for treatment of anxiety and depression, agents with 5-HT2A receptor antagonistic property appear to have a unique role in treating neuropsychiatric diseases. Several antidepressants, including mirtazapine, nefazodone, and trazodone have 5-HT2A receptor antagonistic properties that may contribute to their unique antidepressant effect. Atypical antipsychotics not only are antagonists of dopamine D2 receptors (as with the conventional antipsychotics), but they also block 5-HT2A and 5-HT2C receptors (Meltzer et al., 1989; Markowitz et al., 1999). In addition to treating psychosis, most atypical antipsychotics have indications for bipolar mania, and some have shown efficacy in ameliorating symptoms of depression (Tohen et al., 2003; Calabrese et al., 2005; Berman et al., 2007; Marcus et al., 2008; Bauer et al., 2009). Although the exact mechanism remains to be unknown, facilitating dopamine and norepinephrine neurotransmission (Schmidt and Fadayel, 1995; Zhang et al., 2000) and/or enhancing 5-HT1A receptor action (Marek et al., 2003) may contribute to this therapeutically relevant action of 5-HT2A receptor antagonists.

The brain's serotonergic system is highly complex, in part due to its diffusely distributed multiple receptor subtypes and the signal transduction pathways regulated by these receptors. Therefore, identifying intracellular signaling molecules that direct 5-HTregulated signals to specific physiological and behavioral effects may facilitate our understanding of brain 5-HT function and its 
role in neuropsychiatric diseases. Below we review current findings on the interrelationship between 5-HT and glycogen synthase kinase-3 (GSK3), with an emphasis on the type 1 and type $25-\mathrm{HT}$ receptors.

\section{EFFECTS OF 5-HT ON REGULATING GSK3 5-HT REGULATES GSK3 BY PHOSPHORYLATION}

5-hydroxytryptamine was first found to regulate GSK3 in mouse brain. When wild type mice received an acute administration of d-fenfluramine, a drug that enhances 5 -HT release and blocks 5-HT reuptake, phosphorylation of GSK3 $\beta$ at serine- 9 residue was significantly increased in the cerebral cortex, hippocampus, and striatum (Li et al., 2004). Phosphorylation of this residue transforms the N-terminal of GSK3 into a pseudosubstrate which blocks other GSK3 substrates from entering the active site of the enzyme, thus, d-fenfluramine treatment results in inhibition of GSK3 $\beta$ in the brain. However, even in the presence of a MAOI that blocks the metabolism of 5-HT, the effect of a single intraperitoneal injection of $\mathrm{d}$-fenfluramine is transient, peaking at $1 \mathrm{~h}$, and gradually returning to baseline level by $4 \mathrm{~h}$. This could be due to rapid metabolism of the drug in mice, but rapid release of 5-HT may cause negative feedback inhibition of 5-HT release as well as 5-HT receptor desensitization; both may also contribute to the transient effect of d-fenfluramine on GSK3 phosphorylation.

The inhibitory control of GSK3 by 5-HT is further demonstrated by an elegant study (Beaulieu et al., 2008b) in a mouse model where mice carry a mutation in the tryptophan hydroxylase-2 (TPH-2) gene that is equivalent to a rare human variant $(\mathrm{R} 441 \mathrm{H})$ identified in a few individuals with major depressive disorder (Zhang et al., 2005). The homozygous mutant mice, when compared to littermate wild type mice, have significantly lower levels of the 5-HT precursor 5-hydroxytryptophan (5-HTP), 5-HT, and its metabolite 5-Hydroxyindoleacetic acid (5-HIAA) in the frontal cortex, hippocampus, and striatum. Meanwhile, the level of phosphorylated serine- 9 of GSK3 $\beta$ is significantly lower, and GSK3 activity is elevated in the same brain regions of the mutant mice (Beaulieu et al., 2008b). Therefore, a sustained deficiency of 5-HT may reset the activity level of GSK3 in brain to higher level, compared to wild type mice where the constitutively active GSK3 is likely under inhibitory regulation (Doble and Woodgett, 2003). The overactive GSK3 in the $\mathrm{R} 441 \mathrm{H}$ mutant mice may be involved in the behavioral abnormalities of these mice, since the depressive- and anxiogeniclike behavioral phenotypes of these mice were largely reversed by a GSK3 inhibitor, and by genetically reducing the level of GSK3$\beta$.

\section{BEHAVIORAL SIGNIFICANCE OF GSK3 REGULATION BY 5-HT}

Regulation of GSK3 by 5-HT may have functional significance in maintaining brain physiology and behaviors that are regulated by serotonergic neurotransmission. The 5-HT reuptake inhibitor antidepressant fluoxetine has been shown to increase phosphoSer9-GSK3 $\beta$ in the cerebral cortex, hippocampus, striatum, and cerebellum of mouse brain (Li et al., 2004, 2007; Beaulieu et al., 2008b) and phospho-Ser21-GSK3 $\alpha$ in the hippocampus (Polter et al., 2011). Several studies also suggest that inhibition of GSK3 $\beta$ is an important intermediate step in the antidepressant effect of fluoxetine. In the TPH-2 mutant mice, abnormal behavior associated with 5-HT deficiency is mediated by GSK3 $\beta$ (Beaulieu et al., 2008b). Additionally, inhibition of GSK3 by small molecule inhibitors or in GSK3 $\beta$-deficient mice have been shown to reduce immobility in the forced swim test (Gould et al., 2004; Kaidanovich-Beilin et al., 2004; O'Brien et al., 2004; Beaulieu et al., 2008a; Rosa et al., 2008), similarly to the antidepressants fluoxetine (Page et al., 1999; Bianchi et al., 2002). We have recently tested this behavioral effect of fluoxetine in mutant GSK3 knock-in (KI) mice in which serine- 9 of GSK3 3 or serine- 21 of GSK3 $\alpha$ was substituted with alanine (S9A-GSK3 $\beta$-KI and S21A-GSK3 $\alpha-\mathrm{KI}$; McManus et al., 2005; Polter et al., 2010). These mice have normal levels of GSK3 $\beta$ and GSK $3 \alpha$, but the N-terminal serine cannot be regulated by phosphorylation. In the forced swim test (Porsolt et al., 1977) the baseline immobility (saline treatment) was not significantly different between S9A-GSK3 $\beta$-KI, S21A-GSK3 $\alpha$-KI, and littermate wild type mice. As expected, wild type mice responded to fluoxetine $(20 \mathrm{mg} / \mathrm{kg}$, i.p., $30 \mathrm{~min})$ with a significant $56 \%$ reduction in immobility when compared to saline-treated mice. However, the anti-immobility effect of fluoxetine in S9A-GSK3 $\beta$-KI mice was markedly diminished, with only $17 \%$ non-significant reduction of immobility (Polter et al., 2011). Although fluoxetine was able to increase phospho-Ser21-GSK3 $\alpha$ in the hippocampus, S21AGSK3 $\alpha$-KI mice partially responded to fluoxetine in the forced swim test. Therefore, phosphorylation of GSK3 $\beta$ predominantly mediates the acute antidepressant-like effect of fluoxetine, which reinforces the importance of phosphorylation of GSK3 $\beta$ in the therapeutic action of fluoxetine (Figure 1).

Since the antidepressant effect of fluoxetine in human only appears after chronic administration, to associate GSK3 regulation by fluoxetine to a therapeutic effect, it is important to determine if chronic fluoxetine treatment also regulates GSK3 $\beta$. This has recently be reported by Okamoto et al. (2010) who found that chronic fluoxetine administration for 3 weeks significantly increased phospho-Ser9-GSK3 $\beta$ in mouse hippocampus. Although this is the only selective 5-HT reuptake inhibitor thus far shown to increase phospho-Ser9-GSK3 $\beta$ upon chronic treatment, a dual-acting antidepressant venlafaxine (blocks both 5-HT and norepinephrine transporters) has also been shown to increase phospho-Ser9-GSK3 $\beta$ after chronic administration (Okamoto et al., 2010). When investigating the effect of chronic treatment with imipramine, a TCA that inhibits reuptake of both 5-HT and norepinephrine on activation of Akt and down-stream transcription factor FoxO3a (Polter et al., 2009), we also noticed a significant increase in the level of phospho-Ser9-GSK3 $\beta$ in the cerebral cortex, hippocampus, and striatum of mouse brain after 4 weeks of intraperitoneal administration (Figure 2). It is not yet verified if the effect of venlafaxine and imipramine on GSK3 $\beta$ is a combined action via both 5-HT and norepinephrine, as regulation of brain GSK3 $\beta$ by selective adrenergic-enhancing drugs has not been studied.

\section{REGULATION OF GSK3 BY 5-HT1A RECEPTORS ACTIVATION OF 5-HT1A RECEPTORS REGULATES GSK3 BY PHOSPHORYLATION}

With many physiological actions of brain 5-HT that are divergently mediated by 5 -HT receptor subtypes, it is critically important to 


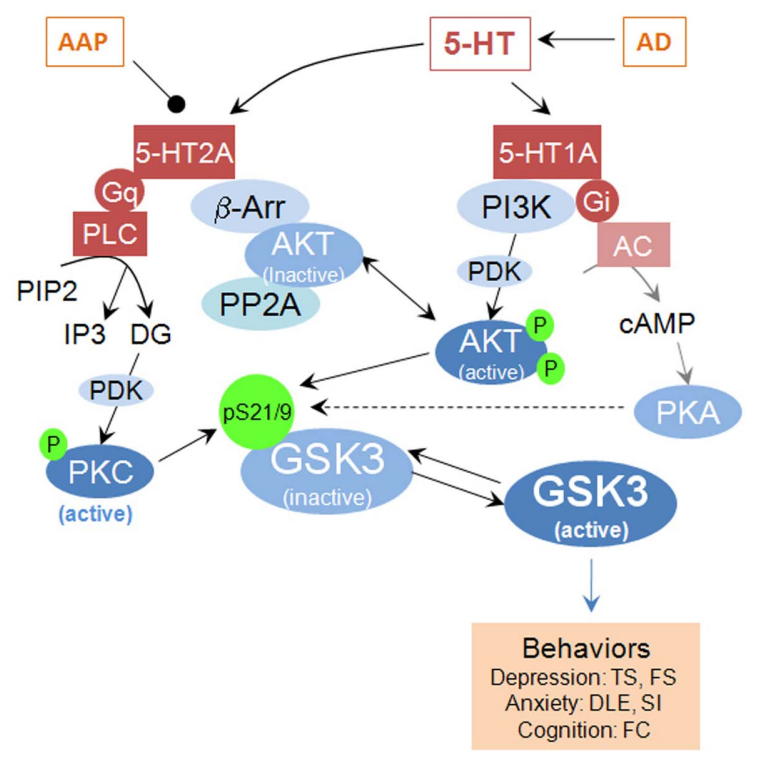

FIGURE 1 | Schematic illustration of GSK3 as an intermediate modulator of 5-HT receptor-mediated signaling pathways and physiological functions. AAP, atypical antipsychotic; $\alpha, \beta, \gamma$, G-protein subunits; $A C$, adenylyl cyclase; $A D$, antidepressant; $\beta$-arr, $\beta$-arrestin; $D G$, diacylglycerol; Gi/Gq, G-protein; GSK3, glycogen synthase kinase-3; $5 \mathrm{HT}$, serotonin; 5-HT1A and 5-HT2A, serotonin receptor subtypes; $P$, phosphorylated; PDK1, phosphoinositide-dependent kinase-1; PI3K, phosphatidylinositol-3-kinase; PP1/PP2A: protein phosphatase 2A; PKA, protein kinase $A$; PKC, protein kinase C. TS, tail suspension; FS, forced swim; DLE, dark-light emergence; SI, social interaction; FC, fear conditioning.

determine the receptor subtypes that transduce 5 - $\mathrm{HT}$ signal to inhibition of GSK3. In mice treated with d-fenfluramine, the 5HT1A receptor antagonist WAY 100635 was able to block over 60\% of d-fenfluramine-induced increase in phospho-Ser9-GSK3 $\beta$, suggesting that 5 -HT1A receptors have a major role in mediating the GSK3-regulating effect of 5-HT. Indeed, when mice receive a single systemic administration of 5-HT1A receptor agonist 8hydroxy- $N, N$-dipropyl-2-aminotetralin (8-OH-DPAT), the level of phospho-Ser9-GSK3 $\beta$, but not total GSK3 $\beta$, is significantly increased in the cerebral cortex, hippocampus, and striatum ( $\mathrm{Li}$ et al., 2004). 8-OH-DPAT is also able to increase the level of phospho-Ser21-GSK3 $\alpha$ in the hippocampus, but the effect is less robust (Polter et al., 2011).

In the hippocampus, a brain area that is enriched in 5-HT1A receptors (Hoyer et al., 2002), GSK3 $\beta$ is ubiquitously expressed with high level of immunoreactivity in neuronal cell bodies and dendritic processes (Peineau et al., 2007; Perez-Costas et al., 2010). 8 -OH-DPAT-induced increase in phospho-Ser9-GSK3 $\beta$ is particularly prominent in the dendrites and cell bodies of CA3, and is observable in the cell bodies and projections of dentate granule cells and the dendrites of CA1 (Polter et al., 2011). The quantified ratio of phospho-Ser9-GSK3 $\beta$ to nuclear marker in the subfields of the hippocampus reveals significant increases in the stratum pyramidale and the stratum radiatum/stratum lucidum of CA3 and in the hilus of the dentate gyrus. Therefore, the response of GSK3 $\beta$

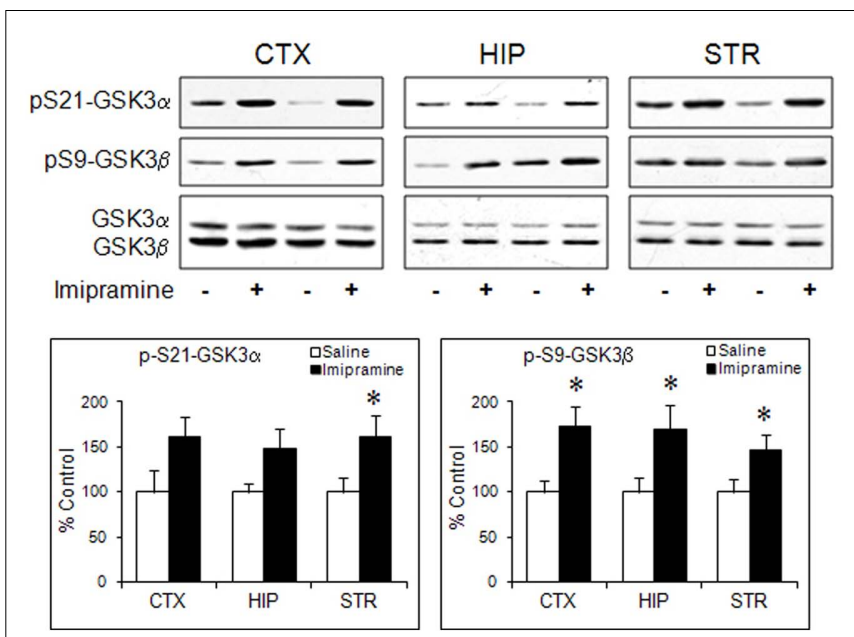

FIGURE 2 | Regulation of phospho-Ser-GSK3 by chronic imipramine treatment in mouse brain. $\mathrm{C} 57 \mathrm{BL} / 6$ mice were treated with imipramine $(20 \mathrm{mg} / \mathrm{kg} / \mathrm{d}$, i.p.) for 28 days before brain dissection. Homogenates of the cerebral cortex (CTX), hippocampus (HIP), and striatum (STR) were immunoblotted for phospho-Ser21-GSK3 $\alpha$, phospho-Ser9-GSK3 $\beta$, total GSK3 $\alpha$ and total GSK3 $\beta$, and data are quantified by densitometry. Protein levels in imipramine-treated samples are calculated as percentage control (saline treatment). Data are mean \pm SEM. ${ }^{*} p<0.05$ ( $n=7-9$ per group) when values are compared to saline treatment in Student's $t$-test.

to systemic administration of 8-OH-DPAT in the hippocampus is preferentially in the pyramidal glutamatergic neurons and their dendrites, suggesting that regulation of GSK3 $\beta$ by 5 -HT1A receptors may have functional impact on the glutamatergic circuits of the hippocampus. GSK3 $\beta$ has been shown to be a mediator of glutamate receptor activity and synaptic plasticity in the hippocampus (Hooper et al., 2007; Peineau et al., 2007; Du et al., 2010), thus regulation of GSK3 $\beta$ by 5-HT1A receptors in the hippocampus may further link this 5 -HT signaling mechanism to hippocampal regulation of learning and memory.

\section{THE ROLE OF GSK3 IN 5-HT1A RECEPTOR-REGULATED BEHAVIORS AND OTHER PHYSIOLOGICAL FUNCTIONS}

Among 5-HT1A receptor-regulated behaviors, inhibition of contextual fear conditioning, a form of associative learning (Kim and Jung, 2006), is a hippocampus-dependent function (Stiedl et al., 2000; Tsetsenis et al., 2007; Ogren et al., 2008). To determine the role of GSK3 $\beta$ in 5-HT1A receptor-regulated fear conditioning, we tested the expression of contextual and cued fear responses in S9A-GSK3 $\beta$-KI, S21A-GSK3 $\alpha-K I$, and littermate wild type mice. In wild type mice, $8-\mathrm{OH}-\mathrm{DPAT}(1 \mathrm{mg} / \mathrm{kg}$, i.p.) injected $30 \mathrm{~min}$ prior to contextual test completely suppressed a standard fear conditioning training-induced contextual freezing (Polter et al., 2011). Compared to wild type mice, S9A-GSK3 $\beta$-KI mice also exhibited increased freezing in contextual tests, but 8-OH-DPAT had no significant effect in reducing the context freezing. In contrast to S9A-GSK3 $\beta$-KI mice, S21A-GSK3 $\alpha$-KI mice responded to 8 -OH-DPAT in contextual freezing similarly as wild type mice. Thus, inhibition of GSK3 $\beta$, but not GSK3 $\alpha$, via 5-HT1A receptors is a necessary intermediate process for 5 -HT1A receptor-regulated inhibition of contextual fear learning. This function of GSK3 $\beta$ is 
selective to the contextual content since the response of cued fear learning to 8-OH-DPAT was similar in S9A-GSK3 $\beta$-KI mice and wild type mice.

The functional significance of GSK3 $\beta$ in 5-HT1A receptormediated physiological functions is not limited to contextual fear learning. In cultured rat hippocampal neurons, 5-HT1A receptor activation by 8-OH-DPAT increases phospho-Ser9-GSK3 $\beta$ and stimulates mitochondrial movements in the axons, an effect mimicked by a GSK3 inhibitor (Chen et al., 2007). This finding suggests the importance of GSK3 $\beta$ in 5-HT1A receptor-mediated regulation of energy distribution in neurons. In Drosophila, overexpressing the mammalian 5-HT1A receptor ortholog d5-HT1B receptor increases the level of phosphorylated serine of SHAGGY (SGG), the Drosophila GSK3 $\beta$ (Yuan et al., 2005). This inhibitory regulation of SGG by d5-HT1B receptor prevents SGG from phosphorylating timeless (TIM) protein for light-induced degradation. Therefore, d5-HT1B receptor reduces behavioral phase shifts in Drosophila by increasing phospho-Ser-SGG. The role of GSK3 in other 5-HT1A receptor-mediated functions remains to be elucidated, but this could be an exciting area in therapeutic drug development, as GSK3 inhibitors, when applied appropriately, may rescue abnormal physiology and behaviors due to functional deficiency of 5-HT1A receptors in brain.

\section{SIGNALING MECHANISMS MEDIATING THE EFFECT OF 5-HT1A RECEPTORS ON GSK3}

5-HT1A receptors activate Gi-coupled signal pathways. In a recent study, Talbot et al. (2010) found that mice expressing regulators of $\mathrm{G}$ protein signaling (RGS)-insensitive Gi 2 have increased sensitivity to 8-OH-DPAT-induced activation, and exhibit elevated levels of cortical and hippocampal phospho-Ser9-GSK3 $\beta$. This effect of RGS-insensitive active Gi 2 was blocked by the 5-HT1A receptor antagonist WAY100635. This finding suggests that regulation of GSK3 $\beta$ by 5 -HT1A receptors is mediated by a Gi-coupled signaling pathway (Figure 1). However, activation of Gi $\alpha 2$ results in inhibition of adenylyl cyclase and inactivation of PKA. Although PKA is one of the several protein kinases that phosphorylate GSK3 $\beta$ on the serine-9 residue (Fang et al., 2000; Li et al., 2000), it is unlikely that this conventional Gi $\alpha$-coupled signaling pathway is responsible for direct phosphorylation of GSK3 $\beta$. Alternatively, 5-HT1A receptor agonists have consistently shown to increase Akt phosphorylation in neuronal cells, including hippocampal derived HN2-5 cells (Adayev et al., 1999), primary hippocampal neurons (Cowen et al., 2005; Chen et al., 2007), and primary fetal rhombencephalic neurons (Druse et al., 2005). Regulation of Akt by 5 -HT1A receptors is mediated by phosphoinositide 3-kinase (PI3K; Cowen et al., 2005; Hsiung et al., 2005, 2008), and is sensitive to inhibition of Gi $\alpha$ activity by pertussis toxin (Cowen et al., 2005). Furthermore, activation of Akt by 5-HT1A receptors can be inhibited by cAMP and restored after inactivation of PKA (Hsiung et al., 2008). Therefore, 5-HT1A receptor-induced activation of Akt likely follows 5-HT1A receptor-induced activation of the Gi $\alpha$-adenylyl cyclase-cAMP-PKA signaling pathway. Since Akt is another major protein kinase that regulates phospho-Ser9-GSK3 $\beta$ (Cross et al., 1995), Akt may mediate 5-HT1A receptor-induced GSK3 $\beta$ phosphorylation. Indeed, systemic treatment of mice with the 5-HT1A receptor agonist 8-OH-DPAT significantly increased the active phospho-Thr308-Akt in the hippocampus, and intrahippocampal infusion of the PI3K inhibitor LY294002 blocked both phospho-Thr308-Akt and phospho-Ser9-GSK3 $\beta$ in response to 8-OH-DPAT (Polter et al., 2011).

\section{SELECTIVITY OF GSK3 REGULATION BY 5-HT1A RECEPTORS}

As discussed above, activation of 5-HT1A receptors increases both phospho-Ser9-GSK3 $\beta$ and phospho-Ser21-GSK3 $\alpha$ in the hippocampus, however, the magnitude of response in GSK3 $\alpha$ is smaller than GSK3 $\beta$ (Polter et al., 2011). Additionally, regulation of GSK $3 \alpha$ phosphorylation by 5 -HT1A receptors has less impact in fear conditioning (Polter et al., 2011). These pilot studies suggest different roles of GSK3 isoforms in mediating the physiological and behavioral functions of 5-HT1A receptors. Additional studies are needed to differentiate the response of GSK3 $\alpha$ and GSK3 $\beta$ to 5 HT1A receptor agonists in different brain regions, and to compare the impact of each GSK3 isoform in other 5-HT1A receptorregulated behaviors, which may provide valuable information on the physiological and behavioral impacts of the two GSK3 isoforms in 5-HT neurotransmission.

A caveat of studying 5-HT1A receptor-regulated signaling in brain is that the differential functions of 5-HT1A autoreceptors and heteroreceptors in different brain regions have divergent functions. Thus, systemic treatment of animals with 5-HT1A receptor agonists can activate 5-HT1A autoreceptors to reduce firing of raphe 5-HT neurons projected to other brain regions, but simultaneously activate 5-HT1A heteroreceptors in those brain regions, such as the hippocampus. Therefore, the effect seen after global activation of 5-HT1A receptors may involve indirect response of GSK3 to activation or inhibition of other neurotransmitters. Therefore, additional studies of GSK3 regulation by systemically and regionally applied 5-HT1A receptor agonists in specific neuron populations in combination with studies in isolated primary neuron cultures will further elucidate the sophisticated mechanisms underlying the GSK3-regulating effect of 5-HT1A receptors. Nevertheless, the effect of global activation of 5-HT1A receptors should be appreciated since systemic drug treatment is likely more relevant to therapeutic implications.

\section{REGULATION OF GSK3 BY 5-HT2A RECEPTORS THE PARADOXICAL EFFECTS OF 5-HT2A RECEPTOR AGONISTS AND ANTAGONISTS ON GSK3}

Although 5-HT1A receptors have a prominent regulatory effect on GSK3, more than one 5-HT receptor subtype should be activated upon elevated brain 5-HT. Among them, 5-HT2A receptors have been found to regulate GSK3 with rather sophisticated and yet unidentified mechanisms. We previously reported that activation of 5-HT2A receptors by systemic administration of 1(2,5-dimethoxy-4-iodophenyl)-propan-2-amine (DOI) for $1 \mathrm{~h} \mathrm{(a}$ time point that maximally increases phospho-Ser9-GSK3 $\beta$ by dfenfluramine, fluoxetine, and 8-OH-DPAT), had little effect on phospho-Ser9-GSK3 $\beta$ in the cerebral cortex, hippocampus, or striatum (Li et al., 2004). However, Abbas et al. (2009) later reported that a brief 15-min DOI treatment caused an increase in phospho-Ser9-GSK3 $\beta$ in the mouse brain, although this report did not specify the brain region in which this effect was seen. If the time length of treatment is the major difference of the discrepant 
findings, one possibility is that $1 \mathrm{~h}$ treatment might have caused desensitization of 5-HT2A receptors. Therefore a thorough kinetic study of 5-HT2A receptor agonists may further clarify their effect on GSK3, especially the effects in different brain regions.

Since activation of 5-HT2A receptors by the hallucinogen DOI is somewhat different from 5-HT-induced activation of 5-HT2A receptors (Schmid et al., 2008), the exact action of 5-HT2A receptor activation on GSK3 phosphorylation should be further elucidated using endogenous 5-HT2A receptor agonists and selective 5-HT2A receptor antagonists. However, this has been difficult to study with 5-HT2A receptors, because it is already known that endogenous 5-HT increases phospho-Ser-GSK3 by activating other 5-HT receptors, particularly 5-HT1A receptors (Li et al., 2004); whereas selective blocking 5-HT2A receptors with their antagonists, one of the commonly used manipulations to determine a receptor-selective effect, paradoxically elicit robust increase in the level of phospho-Ser-GSK3 in mouse brain. This phenomenon was first observed with the non-selective 5-HT2 receptor antagonist LY53857 (Li et al., 2004). Systemic LY53857 treatment not only caused a prolonged elevation of phospho-Ser9GSK3 $\beta$, but it also potentiated the GSK3 $\beta$-regulating effect of $\mathrm{d}$ fenfluramine and 8-OH-DPAT. This effect has also been observed using the 5-HT2A receptor-selective antagonist MDL11939, which elevates both phospho-Ser21-GSK3 $\alpha$ and phospho-Ser9-GSK3 $\beta$ in mouse brain, with the effect more prominent in the cerebral cortex and striatum and less in the hippocampus (Figure 3A).

\section{THE EFFECT OF ATYPICAL ANTIPSYCHOTICS ON GSK3}

Despite the paradoxical nature of 5-HT2A receptors in regulating GSK3, the effect of 5-HT2A receptor antagonists may have clinical significance. Several independent studies have found that antipsychotic drugs, including both conventional and atypical antipsychotics, regulate GSK3 in animal brain. The conventional antipsychotic haloperidol was reported to either alter the phosphorylation state or increase the protein level of GSK3 (Alimohamad et al., 2005; Kozlovsky et al., 2006; Roh et al., 2007). A group of atypical antipsychotics, including risperidone, olanzapine, clozapine, quetiapine, and ziprasidone, were consistently found to increase phospho-Ser-GSK3 in mouse brain (Alimohamad et al., 2005; Li et al., 2007; Roh et al., 2007). Although the dopamine D2 receptor-blocking property of these agents may be involved in their GSK3-regulating effect (Beaulieu et al., 2009), one of the major pharmacological difference between conventional antipsychotics and atypical antipsychotics is that the latter group has a dual antagonistic action on both 5-HT2 receptors and dopamine D2 receptors (Schotte et al., 1995). In our study, a low dose haloperidol that binds to D2 receptors but not 5-HT2A receptors had no effect on mouse brain GSK3 (Li et al., 2007). In contrast, systemic administered risperidone increases brain phospho-Ser9-GSK3 $\beta$ at a dose as low as $0.1 \mathrm{mg} / \mathrm{kg}$ (Li et al., 2007). As the average dose of risperidone used to attain a $50 \%$ in vivo blockade of D2 receptors in rats is about $0.3 \mathrm{mg} / \mathrm{kg}$ (Kapur et al., 2003), and the binding affinity of risperidone to 5-HT2A receptors is at least 3 times higher than to D2 receptors (Weiner et al., 2001), it is likely that the increase of phospho-Ser9-GSK3 $\beta$ by the low dose risperidone involves blocking 5-HT2A receptors. It remains to be determined if putative 5-HT2A receptor antagonists have similar clinical implications

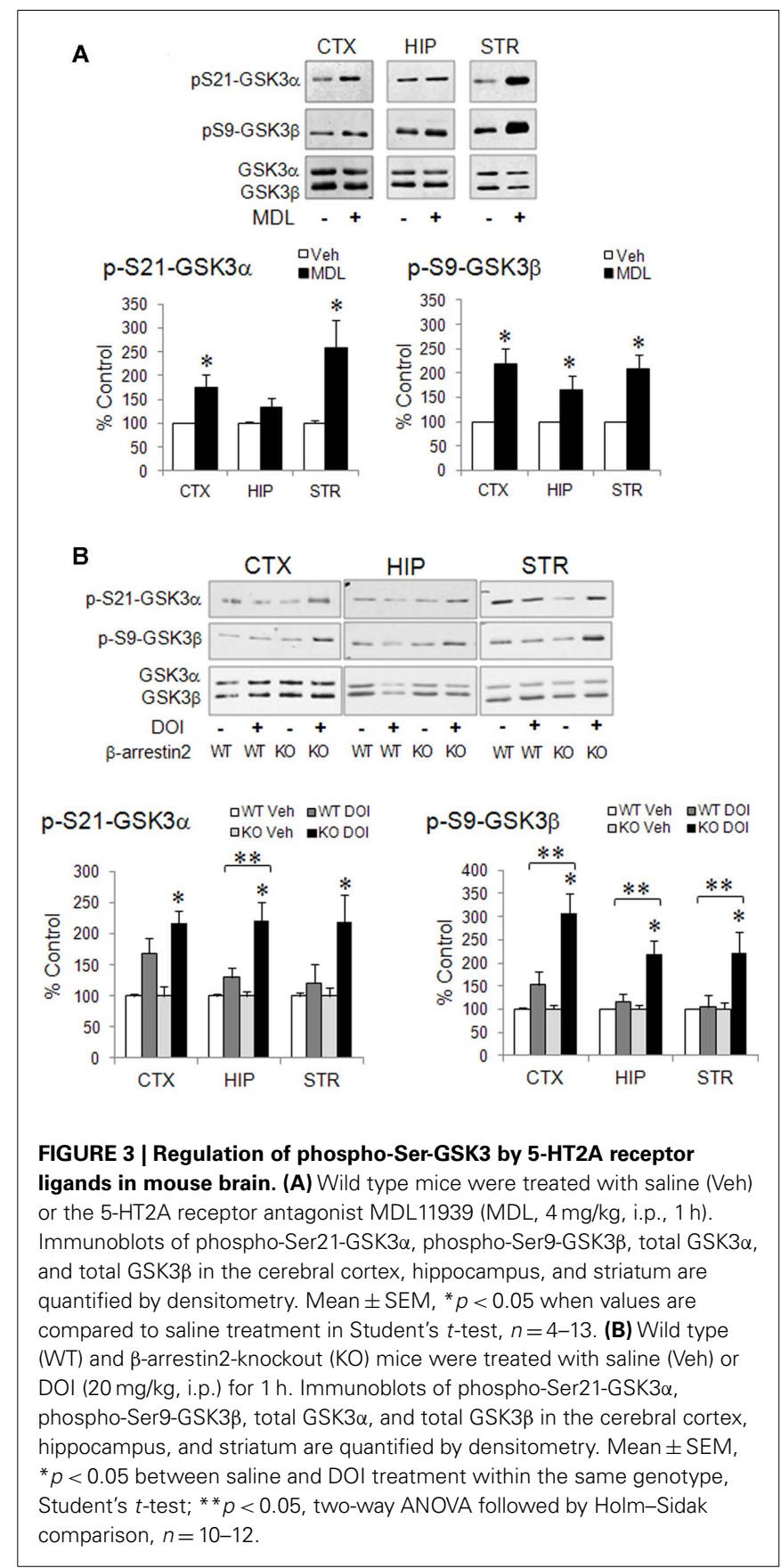

as atypical antipsychotics, and if such effects are dependent on regulation of GSK3.

Clinically, atypical antipsychotics have indications in both psychotic disorders and mood disorders (Derry and Moore, 2007; Philip et al., 2008). Some atypical antipsychotics, either as monotherapy or augmentation, have shown efficacy in ameliorating symptoms of depression (Tohen et al., 2003; Calabrese et al., 2005; Berman et al., 2007; Marcus et al., 2008; Bauer et al., 2009). Interestingly, a combination treatment with risperidone and fluoxetine enhance the effect of either agent alone on phosphorylation of GSK3 $\beta$ in the rodent brain (Li et al., 2007). This effect agrees 
with the finding that the 5-HT2 receptor antagonist LY53857 potentiated the effect of d-fenfluramine and 8-OH-DPAT on GSK3 phosphorylation. However, the role of GSK3 in this clinically relevant combination effect between antidepressants and atypical antipsychotics remains to be determined.

\section{SIGNALING MECHANISMS INVOLVED IN REGULATION OF GSK3 BY 5-HT2A RECEPTORS}

Few studies have investigated the signaling mechanisms that mediate the effects of either 5-HT2A receptor agonists or antagonists on GSK3 phosphorylation. Classically, the 5-HT2A receptors couple to Gq protein that activates PLC and its down-stream PKC (Carr et al., 2002; Figure 1). PKC was reported to mediate DOIinduced Erk phosphorylation in the brain (Schmid et al., 2008). Since PKC is one of the protein kinases that regulate GSK3 phosphorylation (Goode et al., 1992), it would be straightforward if the PLC/PKC signaling mechanism is found to mediate 5-HT2A receptor-regulated GSK3. However, this mechanism has not been reported, especially since the kinetic correlation between 5-HT2A receptor activation and phosphorylation of GSK3 has not been characterized. In a study of dopamine D2 receptor-regulated signaling (Beaulieu et al., 2004), the intracellular scaffolding protein $\beta$-arrestins were found to negatively affect GSK3 phosphorylation in mouse brain, wherein activation of dopamine D2 receptors reduces phospho-Ser9-GSK3 due to inactivation of Akt by protein phosphatase-2 (PP2A) in a $\beta$-arrestin2-driven protein complex (Beaulieu et al., 2005). D2 receptor antagonists block this effect of dopamine and increase phospho-Ser-GSK3 by disrupting the effect of $\beta$-arrestins. 5-HT2A receptors also interact with $\beta$ arrestins in a cell type- and ligand-selective manner (Gelber et al., 1999; Allen et al., 2008; Schmid et al., 2008; Schmid and Bohn, 2010 ), but the role of $\beta$-arrestins in 5-HT2A receptor-regulated signal pathways is less understood. It should be noted that in a previous study by Schmid et al. (2008), DOI-induced head twitch, receptor internalization, and Erk phosphorylation are not dependent on the presence or absence of $\beta$-arrestins. However, we have recently found that DOI treatment for $1 \mathrm{~h}$ induced a significant over twofold increase in phospho-Ser21-GSK3 $\alpha$ and phosphoSer9-GSK3 $\beta$ in the cerebral cortex, hippocampus, and striatum in $\beta$-arrestin2-knockout mice, an effect that is not seen in wild type mice (Figure 3B). This observation suggests that $\beta$-arrestin2 may influence how 5-HT2A receptors regulate GSK3. Future studies investigating signal transduction mechanisms mediating the effect of 5-HT2A receptors on GSK3 should include not only PLC/PKC signaling, but also $\beta$-arrestin-mediated signaling. Additionally, since 5-HT2A receptors are involved in modulating dopamine neurotransmission (Alex and Pehek, 2007; Di Giovanni et al., 2008; Esposito et al., 2008), a potential indirect effect of 5HT2A receptors on D2 receptor-regulated GSK3 should also be considered.

\section{GSK3 SELECTIVELY REGULATES 5-HT1B RECEPTOR-MEDIATED SIGNAL TRANSDUCTION AND FUNCTION}

Glycogen synthase kinase-3 phosphorylates many protein substrates that distribute in both neural and peripheral tissues (Woodgett, 2001; Jope and Johnson, 2004). As a result, in vivo inhibition of GSK3 can have a variety of physiological effects. Thus, identifying GSK3 substrates that have specific functions in brain circuits could be critical in developing GSK3-targeting treatment for therapeutics. With each clearly identified substrate, substrate-targeting inhibition of brain GSK3 activity may lead to selective modulation of physiological function of the brain. Most 5-HT receptor subtypes, except 5-HT3 receptors, are G-protein coupled receptors (GPCRs) that represent the largest group of drug targets. Besides activation by receptor ligands, the activity of GPCRs can be modulated by posttranslational modifications, such as phosphorylation by protein kinases (Tobin, 2008), or interaction with intracellular proteins (Ritter and Hall, 2009; Bockaert et al., 2010). However, little evidence has shown GPCR regulation by GSK3.

\section{DIRECT INTERACTION BETWEEN GSK3 $\beta$ AND 5-HT1B RECEPTORS}

In an effort to identify GSK3 substrates within the 5-HT neurotransmission system, we searched GSK3 consensus phosphorylation sequence for primed substrates - pre-phosphorylated by a serine/threonine kinase to allow access of GSK3 to the serine/threonine located four amino acids $\mathrm{N}$-terminal of the primed site (Doble and Woodgett, 2003). Somewhat surprisingly, both human and mouse $5-\mathrm{HT} 1 \mathrm{~B}$ receptors were found to contain eight GSK3 consensus phosphorylation sites spreading within intracellular loops 1, 2, and 3 of the receptor. In contrast, the highly homologous 5-HT1A receptors have no GSK3 consensus sites in intracellular loops 1 and 2, and the two sites in intracellular loop-3 of human 5-HT1A receptors are not homologous with mouse 5-HT1A receptors. In cultured heterologous cells expressing 5 -HT1B or 5-HT1A receptors, GSK3 $\beta$ was found to directly associate with 5-HT1B receptors (Chen et al., 2009), which was detected using the bioluminescence resonance energy transfer (BRET) assay that measures the proximity of two proteins within a distance of 1-10 nm (Angers et al., 2000), and confirmed by coimmunoprecipitation of 5-HT1B receptors and GSK3 $\beta$. Intriguingly, this interaction of GSK3 $\beta$ is selective to $5-\mathrm{HT} 1 \mathrm{~B}$ receptors, as GSK3 $\beta$ does not interact with 5-HT1A receptors (Chen et al., 2009). Mutation of every potential GSK3 consensus phosphorylation site of 5-HT1B receptors by replacing the serine with alanine further shows that GSK3 $\beta$ associates with 5-HT1B receptors at the [pS(154)AKRpT(158)] sequence located in the i2-loop of 5-HT1B receptors (Chen et al., 2009).

\section{GSK3 $\beta$ DIFFERENTIALLY INFLUENCES 5-HT1B RECEPTOR ACTIVITY AND ASSOCIATED SIGNALINGS}

Both 5-HT1B and 5-HT1A receptors couple to Gi-protein, activation of which causes inhibition of adenylyl cyclase and reduction of cAMP. Disrupting the interaction between 5 - $\mathrm{HT} 1 \mathrm{~B}$ receptors and GSK3 $\beta$ by mutating the GSK3 $\beta$-interactive Ser- 154 residue of the receptor (S154A-5-HT1B receptor) effectively abolishes 5-HT-induced conformational change between 5-HT1B receptors and Gi 2 (Chen et al., 2011). In accordance with altered activity of Gi $\alpha 2$, GSK3 $\beta$-insensitive S154A-5-HT1B receptor does not respond to 5-HT in assay of 5-HT-induced inhibition of cAMP (Chen et al., 2009). These data highly suggest that GSK3 $\beta$ has a functional impact on 5-HT1B receptor-mediated signaling. Indeed, several small molecule GSK3 inhibitors and the clinically used lithium are able to disrupt 5-HT-induced conformational 
change between 5-HT1B receptors and Gi 2 and inhibition of cAMP. This is a highly selective function of the GSK3 $\beta$ isoform, as it only occurs in cells with GSK3 $\beta$-knockdown or over-expressing inactive GSK3 $\beta$, but GSK3 $\alpha$-knockdown does not affect 5-HT1B receptor-associated Gi $\alpha$-cAMP signaling (Chen et al., 2009, 2011). This is another example showing that despite GSK3 $\alpha$ and GSK3 $\beta$ are highly homologous and are regulated via similar upstream mechanisms, the two isoforms of GSK3 have different substrates and mediate different physiological functions (Wang et al., 1994; Liang and Chuang, 2006). In agreement with a selective interaction between GSK3 $\beta$ and 5-HT1B receptors, GSK3 inhibitors and molecular manipulation of intracellular GSK3 $\beta$ do not alter 5-HT-induced 5-HT1A receptor-Gi 2 interaction or 5-HT1A receptor-mediated inhibition of cAMP.

Gi $\alpha$-mediated cAMP production is not the only GSK3dependent signaling pathway of 5-HT1B receptors as activation of Akt by 5 -HT or the selective 5 -HT1B receptor agonist anpirtoline is also significantly diminished in the mutant S154A-5-HT1B receptor-expressing cells (Chen et al., 2011). The mechanisms of regulating Akt by $5-\mathrm{HT} 1 \mathrm{~B}$ receptors are not fully understood, but since both $\alpha$ - and $\beta \gamma$-subunits of G-proteins may be linked to GPCR-induced activation of Akt (DeWire et al., 2007; New et al., 2007; Yang et al., 2009), the effect of GSK3 $\beta$ on 5-HT1B receptorinduced Akt activation could be a consequence of the prominent effect of GSK3 $\beta$ on 5-HT1B receptor-associated Gi-protein. In addition, since Akt is one of the upstream GSK3-regulating protein kinases that inactivates GSK3 (Cross et al., 1995), the GSK3-dependent activation of Akt by 5 -HT1B receptors could function as a feedback regulation to prevent prolonged effect of GSK3 $\beta$ on 5 -HT1B receptors, but this postulation remains to be examined.

As a GPCR, 5-HT1B receptors are expected to interact with $\beta$ arrestins that have been recognized to interact with many GPCRs and play important roles in GPCR internalization and alternative signaling (Lefkowitz and Shenoy, 2005). Indeed, we found that $\beta$-arrestin 2 can be recruited to 5 -HT1B receptors in response to 5 -HT. However, in contrast to the prominent effect of GSK3 $\beta$ on 5-HT1B receptor-coupling to Gi 2 , removing, or inhibiting GSK3 $\beta$ did not affect $\beta$-arrestin2 recruitment to 5 -HT1B receptors (Chen et al., 2011). As a chaperone protein, recruitment of $\beta$-arrestins to GPCRs initiates receptor internalization and desensitization (Bohn et al., 1999, 2000). 5-HT was able to internalize both wild type and S154A-5-HT1B receptors in 5-HT1B receptorexpressing cells (Chen et al., 2009). If this internalization event is directed by $\beta$-arrestin 2 , it is in agreement with our finding that $\beta$-arrestin2 recruitment to 5 - $\mathrm{HT} 1 \mathrm{~B}$ receptors is independent of GSK3 $\beta$. However, the time course of 5-HT1B receptor internalization is drastically different between wild type and the mutant S154A-5-HT1B receptors, wherein wild type receptors rapidly reappear on the cell membranes within 60 min of 5-HT treatment, while mutant GSK3 $\beta$-insensitive receptors continue to be absent from the cell surface $2 \mathrm{~h}$ after 5 -HT treatment. This suggests a potentially important function of GSK $3 \beta$ in an unidentified mechanism that is crucial for $5-\mathrm{HT} 1 \mathrm{~B}$ receptor synthesis and membrane recycling.

Interestingly, the effect of GSK3 $\beta$ on 5 -HT1B receptors appears to facilitate activity and functional recovery, which is opposite from other GPCR-regulating protein kinases (GRKs) that typically facilitate desensitization and termination of GPCR activity (Gainetdinov et al., 2004). The underlying importance of GSK3 $\beta$ on 5-HT1B receptor-mediated Gi signaling and $\beta$-arrestin recruitment is that GSK3 $\beta$ does not function as a general 5-HT1B receptor activator, instead, GSK3 $\beta$ selectively modulates signaling-specific actions of $5-\mathrm{HT} 1 \mathrm{~B}$ receptors. This effect of GSK3 $\beta$ could be attractive when developing GSK3-targeting therapeutic agents, as inhibition of GSK3 $\beta$ would not make inert 5 -HT1B receptors, but to selectively shift 5 -HT1B receptor-mediated physiological and behavioral functions toward a Gi signaling-independent direction. This postulation is an important area of future research especially when $\beta$-arrestin-associated 5-HT1B receptor signaling pathways are identified.

\section{EFFECT OF GSK3 INHIBITORS ON THE PHYSIOLOGICAL FUNCTIONS OF 5-HT1B RECEPTORS}

Noticeably, several earlier studies showed that lithium selectively inhibits 5-HT binding to 5-HT1B receptors, reduces 5-HT1B receptor-induced GTP $\gamma$ s binding, and abolishes 5 -HT1B receptorreduced adenylyl cyclase activity (Massot et al., 1999). Similar results have been observed in human platelets from both healthy and depressed subjects where lithium dose-dependently reverses the inhibitory effect of a 5-HT1BR agonist on adenylyl cyclase (Januel et al., 2002). In animal behavior studies, lithium selectively regulates the behavioral effect of 5-HT1B receptor agonists, but not the effect of 5-HT1A receptor agonists (Redrobe and Bourin, 1999). With lithium being a selective GSK3 inhibitor (Klein and Melton, 1996), it is highly likely that the selective effect of lithium on 5-HT1B receptor function is the result of its inhibition of GSK3. Since lithium is a therapeutic drug that has been found to inhibit GSK3 in vivo, perhaps by both its direct and indirect actions on GSK3 (Klein and Melton, 1996; ChaleckaFranaszek and Chuang, 1999; De Sarno et al., 2002), disrupting the interaction between $5-\mathrm{HT} 1 \mathrm{~B}$ receptors and GSK3 $\beta$ may have significant impact in the physiological functions of 5-HT1B receptors and relevant therapeutic effects in neuropsychiatric diseases.

The above postulation has been tested now in mouse brain tissues using small GSK3 inhibitors. When mouse cerebral cortical slices are pre-treated with the GSK3 inhibitors 6-bromoindirubin$3^{\prime}$-oxime (BIO) or kenpaullone, both inhibitors concentrationdependently abolish the inhibitory effect of 5-HT1B receptor agonist anpirtoline on forskolin-stimulated cAMP, whereas neither affects the effect of 5-HT1A receptor agonist 8-OH-DPAT on cAMP (Chen et al., 2009). This finding in brain tissues is consistent with findings in cultured cells, where ablation or inhibition of GSK3 $\beta$ selectively abolishes 5 -HT1B receptor-mediated Gi $\alpha$ cAMP signaling. Furthermore, pre-treatment of cortical slices with the GSK3 inhibitors AR-A014418 (Bhat et al., 2003) and BIP-135 (Gaisina et al., 2009) completely abolish the inhibitory effect of anpirtoline on potassium-evoked ${ }^{3} \mathrm{H}-5-\mathrm{HT}$ release (Chen et al., 2011). Since negatively regulating 5 -HT release is a characteristic function of 5-HT1B autoreceptors in the axon terminals of 5-HT neurons (Trillat et al., 1997; Riad et al., 2000; Sari, 2004), this finding suggests that active GSK3 plays a role to rapidly resets the surge of 5-HT to baseline, which may result in termination 
of a physiological or behavioral action of 5-HT. In reverse, inhibition of GSK3 may be important in maintaining 5-HT at a sufficient level that allows 5-HT to deliver sustained physiological action. The signaling pathways mediating 5-HT1B autoreceptorinduced inhibition of 5-HT release have never been confirmed. In a study conducted in 5-HT1B receptor-expressing cardiac ventricle myocytes, inhibition of 5 -HT release by 5 -HT1B receptors was found to be a pertussis toxin-sensitive Gi-mediated effect, where the effect was not mediated by cAMP, but by an inwardly rectifying potassium channel (Ghavami et al., 1997). However, pertussis toxin-dependent 5 -HT release by 5 -HT1B receptors in the brain has not been confirmed. It should therefore be noted that although GSK3 inhibitors abolish the effect of 5-HT1B receptors on Giassociated signalings and 5-HT release, the latter is not necessarily due to the impaired 5-HT1B receptor-Gi $\alpha$ coupling.

\section{EFFECT OF GSK3 INHIBITORS ON 5-HT1B RECEPTOR-REGULATED BEHAVIORS}

If GSK3 $\beta$ differentially affects 5-HT1B receptor-mediated signal transduction and brain physiological function, it would be expected that GSK3 inhibitors may also differentially affect 5-HT1B receptor-regulated behaviors. Indeed, intracerebroventricular infusion of GSK3 inhibitor AR-A014418 or BIP-135 prior to systemic administration of anpirtoline significantly facilitates the anti-immobility effect of the 5-HT1B receptor agonist in the tail suspension test (Chen et al., 2011). In this behavioral test, low doses of GSK3 inhibitors and anpirtoline are used so that GSK3 inhibitors alone has no effect and anpirtoline alone only mildly reduces the immobility, which highlights the combination effect of GSK3 inhibition and 5-HT1B receptor activation. Finding of this study suggests that GSK3 inhibitors facilitate the anti-immobility effect of 5-HT1B heteroreceptors by abolishing 5-HT1B autoreceptor-mediated inhibition of serotonin release. Interestingly, the anpirtoline-induced increase in horizontal locomotor activity was not altered by GSK3 inhibitors, but is largely diminished in $\beta$-arrestin2-knockout mice (Chen et al., 2011), which is in agreement with the in vitro findings showing that association of $\beta$-arrestin2 with 5 -HT1B receptors does not depend on GSK3 $\beta$. Therefore, these initial behavior data further suggest that GSK3 has differential effects in modulating 5-HT1B receptor functions in brain.

Taken together, molecular and in vivo studies support a prominent effect of GSK3 $\beta$ to selectively regulate 5-HT1B receptor function (Figure 4). The effect of GSK3 $\beta$ is elicited by directly interacting with $5-\mathrm{HT} 1 \mathrm{~B}$ receptors at the intracellular loop-2. This interaction functions to facilitate 5-HT1B receptor-regulated Gi $\alpha$ mediated signaling. In the absence of GSK3 $\beta, 5-\mathrm{HT} 1 \mathrm{~B}$ receptors are dissociated from the conventional Gi $\alpha$-mediated signaling, but still able to respond to agonist-induced recruitment of $\beta$-arrestin2 and receptor internalization. Regulation of $5-\mathrm{HT} 1 \mathrm{~B}$ receptors by GSK $3 \beta$ has functional significance since it impacts 5 -HT1B receptor-dependent 5-HT release. Although this and other physiological functions of the highly selective modulation of 5-HT1B receptors by GSK3 $\beta$ remain to be investigated in further detail, initial evidence supports a significant behavioral impact of this GSK3 action that may be important for therapeutic development. Several important questions remain to be addressed before the importance of this unique effect of GSK3 $\beta$ is completely elucidated. Particularly important is to understand if the effect of GSK $3 \beta$ is selective to 5 -HT1B autoreceptors only or both autoand hetero-receptors, which 5-HT1B receptor-regulated signaling mechanisms in the brain are affected by GSK $3 \beta$, and if the GSK3 $\beta$ dependent signaling pathways correlate with the effect of GSK3 $\beta$ on the physiological and behavioral functions of brain 5-HT1B receptors.

\section{SUMMARY}

Cumulative evidence from in vitro measurements, pharmacological studies, and animal behavioral tests strongly support GSK3 as an integrative mediator of 5-HT neurotransmission. First, GSK3 is an early intracellular responder to a surge of brain 5-HT, which results in GSK3 phosphorylation at an N-terminal serine and inactivation of its constitutive activity. Phosphorylation of GSK3 by increasing brain 5-HT may be therapeutically important as the behavioral effect of fluoxetine is mediated by GSK3 phosphorylation. Second, GSK3 is a down-stream target of 5HT1A receptor signaling, and enhancing GSK3 phosphorylation by 5 -HT1A receptors in the hippocampus is associated with its inhibitory effect on contextual fear learning. Third, 5-HT2A receptors elicit sophisticated regulatory effect on GSK3, as both agonist and antagonist of 5-HT2A receptors may inactivate it, but the effects likely depend on the receptor activation state and the presence of other receptor interactive proteins. Regulation of GSK3 by 5-HT2A receptors may have therapeutic implication as evidenced by the prominent inhibitory effect of atypical antipsychotics on GSK3, presumably related to the 5-HT2A receptor antagonistic effect of these drugs. Finally, GSK3 $\beta$ interacts with and modulates 5-HT1B receptor activity in a receptor subtype- and signaling pathway-selective manner. Although the physiological impact of this action in intact brain remains to be elucidated, it is predicted that this action of GSK3 $\beta$ is to rapidly reset the level of 5-HT in certain brain areas to ameliorate prolonged effect of 5-HT, whereas the therapeutic implication of this unique action of GSK3 remains to be further studied.

The prominent effect of GSK3 on serotonin neurotransmission may partially explain the many findings of behavioral actions of GSK3 as well as it being a converging target of mood stabilizers, antidepressants, and antipsychotics (Li and Jope, 2010). Integrating 5-HT neurotransmission by GSK3 may be particularly indicative in the pathophysiological roles of GSK3 in mood, anxiety, and cognitive disorders that involve dysregulation of 5-HT neurotransmission, and in the therapeutics targeting GSK3 for the treatment of these diseases.

However, our current knowledge on this potentially important function of GSK3 is limited. GSK3 has only been found to associate with 5-HT1A, 5-HT1B, and 5-HT2A receptors. Evidence showing GSK3 as a down-stream target or a modulator of other 5-HT receptor subtypes is still lacking. As discussed in this review, the two isoforms of GSK3 appear to have common and unique relations to different 5-HT receptors, but it is not yet clear if the divergent relationship is receptor subtype- or brain region-specific. Additional investigations are also necessary to fully understand how altered activity of GSK3 affects 5-HT-regulated behaviors, and to determine the mechanisms of how each behavior is affected by 


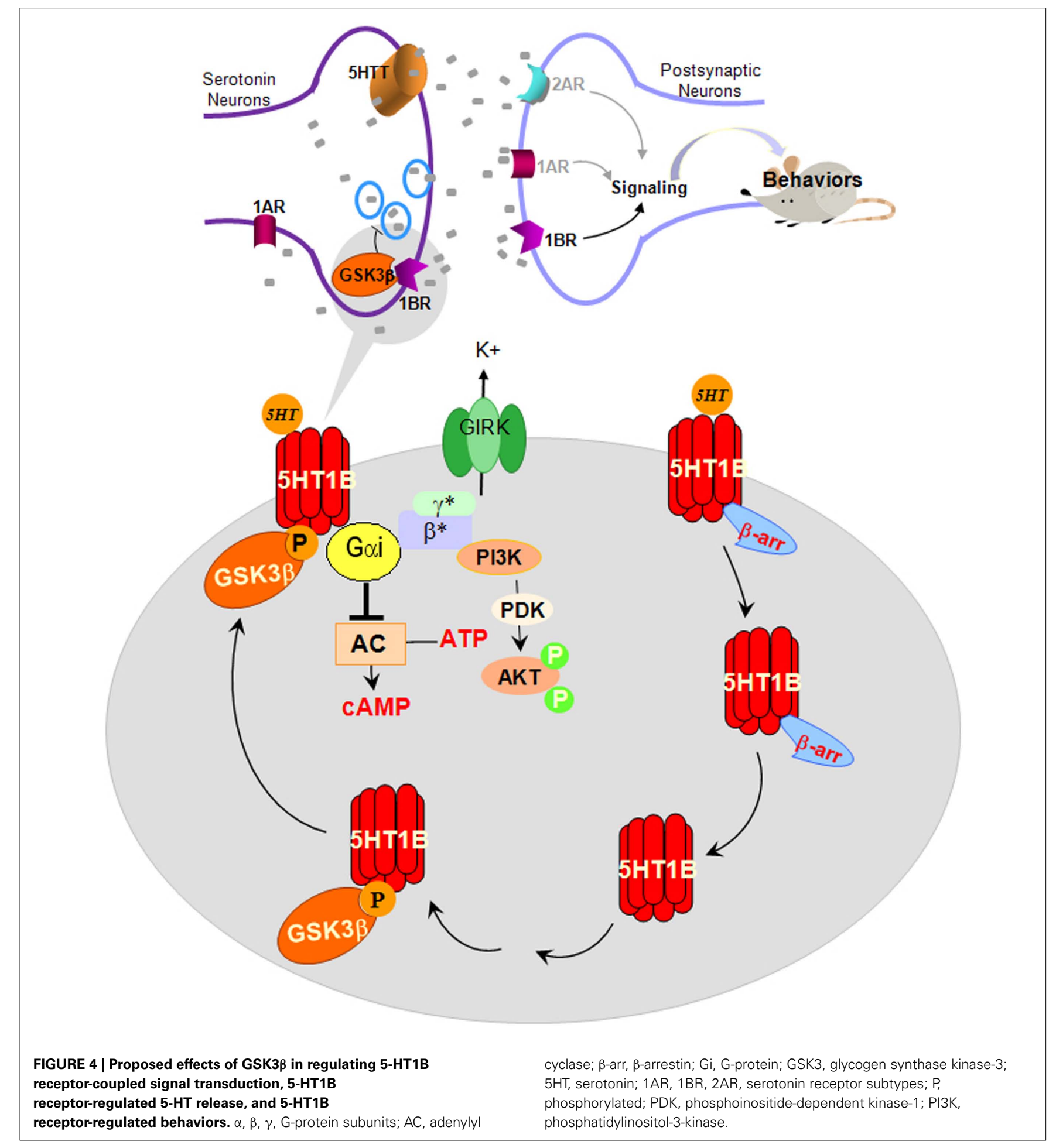

altered GSK3 activity. Since GSK3 is a protein kinase, an important task is to identify specific protein substrates that mediate the divergent physiological and behavioral effects of GSK3 within and beyond 5-HT neurotransmission. Human studies are needed to determine if clinical findings support the ample preclinical evidence suggesting a role of GSK3 in 5-HT dysregulation and related brain disorders. Finally, all the ongoing and future research tasks should converge to developing GSK3 modulators that are able to substitute, facilitate, or supplement therapeutic drugs that are known to modulate 5-HT neurotransmission.

\section{ACKNOWLEDGMENTS}

The corresponding author of this article is supported by NIH grant MH86622. 


\section{REFERENCES}

Abbas, A. I., Yadav, P. N., Yao, W. D., Arbuckle, M. I., Grant, S. G., Caron, M. G., and Roth, B. L. (2009). PSD95 is essential for hallucinogen and atypical antipsychotic drug actions at serotonin receptors. J. Neurosci. 29, 7124-7136.

Adayev, T., El-Sherif, Y., Barua, M., Penington, N. J., and Banerjee, P. (1999). Agonist stimulation of the serotonin $1 \mathrm{~A}$ receptor causes suppression of anoxia-induced apoptosis via mitogen-activated protein kinase in neuronal HN2-5 cells. J. Neurochem. 72, 1489-1496.

Akimova, E., Lanzenberger, R., and Kasper, S. (2009). The serotonin-1A receptor in anxiety disorders. Biol. Psychiatry 66, 627-635.

Albert, P. R., and Lemonde, S. (2004). 5-HT1A receptors, gene repression, and depression: guilt by association. Neuroscientist 10, 575-593.

Alex, K. D., and Pehek, E. A. (2007). Pharmacologic mechanisms of serotonergic regulation of dopamine neurotransmission. Pharmacol. Ther. 113, 296-320.

Alimohamad, H., Rajakumar, N., Seah, Y. H., and Rushlow, W. (2005). Antipsychotics alter the protein expression levels of beta-catenin and GSK-3 in the rat medial prefrontal cortex and striatum. Biol. Psychiatry 57, 533-542.

Allen, J. A., Yadav, P. N., and Roth, B. L. (2008). Insights into the regulation of 5-HT2A serotonin receptors by scaffolding proteins and kinases. Neuropharmacology 55, 961-968.

Angers, S., Salahpour, A., Joly, E., Hilairet, S., Chelsky, D., Dennis, M., and Bouvier, M. (2000). Detection of beta 2-adrenergic receptor dimerization in living cells using bioluminescence resonance energy transfer (BRET). Proc. Natl. Acad. Sci. U.S.A. 97, 3684-3689.

Banasr, M., Hery, M., Printemps, R., and Daszuta, A. (2004). Serotonininduced increases in adult cell proliferation and neurogenesis are mediated through different and common 5 -HT receptor subtypes in the dentate gyrus and the subventricular zone. Neuropsychopharmacology 29, 450-460.

Bauer, M., Pretorius, H. W., Constant, E. L., Earley, W. R., Szamosi, J., and Brecher, M. (2009). Extendedrelease quetiapine as adjunct to an antidepressant in patients with major depressive disorder: results of a randomized, placebo-controlled, double-blind study. J. Clin. Psychiatry 70, 540-549.

Beaulieu, J. M., Gainetdinov, R. R., and Caron, M. G. (2009). Akt/GSK3 signaling in the action of psychotropic drugs. Annu. Rev. Pharmacol. Toxicol. 49, 327-347.

Beaulieu, J. M., Marion, S., Rodriguiz, R. M., Medvedev, I. O., Sotnikova, T. D., Ghisi, V., Wetsel, W. C., Lefkowitz, R. J., Gainetdinov, R. R., and Caron, M. G. (2008a). A beta-arrestin 2 signaling complex mediates lithium action on behavior. Cell 132, 125-136.

Beaulieu, J. M., Zhang, X., Rodriguiz, R. M., Sotnikova, T. D., Cools, M. J., Wetsel, W. C., Gainetdinov, R. R., and Caron, M. G. (2008b). Role of GSK3 beta in behavioral abnormalities induced by serotonin deficiency. Proc. Natl. Acad. Sci. U.S.A. 105, 1333-1338.

Beaulieu, J. M., Sotnikova, T. D., Marion, S., Lefkowitz, R. J., Gainetdinov, R. R., and Caron, M. G. (2005). An Akt/beta-arrestin 2/PP2A signaling complex mediates dopaminergic neurotransmission and behavior. Cell 122, 261-273.

Beaulieu, J. M., Sotnikova, T. D., Yao, W. D., Kockeritz, L., Woodgett, J. R., Gainetdinov, R. R., and Caron, M. G. (2004). Lithium antagonizes dopamine-dependent behaviors mediated by an AKT/glycogen synthase kinase 3 signaling cascade. Proc. Natl. Acad. Sci. U.S.A. 101, 5099-5104.

Berman, R. M., Marcus, R. N., Swanink, R., McQuade, R. D., Carson, W. H., Corey-Lisle, P. K., and Khan, A. (2007). The efficacy and safety of aripiprazole as adjunctive therapy in major depressive disorder: a multicenter, randomized, doubleblind, placebo-controlled study. $J$. Clin. Psychiatry 68, 843-853.

Bhat, R., Xue, Y., Berg, S., Hellberg, S., Ormo, M., Nilsson, Y., Radesäter, A. C., Jerning, E., Markgren, P. O., Borgegård, T., Nylöf, M., Giménez-Cassina, A., Hernández, F., Lucas, J. J., Díaz-Nido, J., and Avila, J. (2003). Structural insights and biological effects of glycogen synthase kinase 3-specific inhibitor AR-A014418. J. Biol. Chem. 278, 45937-45945.

Bianchi, M., Moser, C., Lazzarini, C., Vecchiato, E., and Crespi, F. (2002). Forced swimming test and fluoxetine treatment: in vivo evidence that peripheral 5-HT in rat platelet-rich plasma mirrors cerebral extracellular 5-HT levels, whilst 5-HT in isolated platelets mirrors neuronal 5HT changes. Exp. Brain Res. 143, 191-197.

Blier, P., and Ward, N. M. (2003). Is there a role for 5-HT1A agonists in the treatment of depression? Biol. Psychiatry 53, 193-203.

Bockaert, J., Claeysen, S., Becamel, C., Dumuis, A., and Marin, P. (2006).
Neuronal 5-HT metabotropic receptors: fine-tuning of their structure, signaling, and roles in synaptic modulation. Cell Tissue Res. 326 553-572.

Bockaert, J., Perroy, J., Becamel, C., Marin, P., and Fagni, L. (2010). GPCR interacting proteins (GIPs) in the nervous system: roles in physiology and pathologies. Annu. Rev. Pharmacol. Toxicol. 50, 89-109.

Bohn, L. M., Gainetdinov, R. R., Lin, F. T., Lefkowitz, R. J., and Caron, M. G. (2000). Mu-opioid receptor desensitization by beta-arrestin- 2 determines morphine tolerance but not dependence. Nature 408, 720-723.

Bohn, L. M., Lefkowitz, R. J., Gainetdinov, R. R., Peppel, K., Caron, M. G., and Lin, F. T. (1999). Enhanced morphine analgesia in mice lacking betaarrestin 2. Science 286, 2495-2498.

Bouhelal, R., Smounya, L., and Bockaert, J. (1988). 5-HT1B receptors are negatively coupled with adenylate cyclase in rat substantia nigra. Eur. J. Pharmacol. 151, 189-196.

Calabrese, J. R., Keck, P. E. Jr., Macfadden, W., Minkwitz, M., Ketter, T. A., Weisler, R. H., Cutler, A. J., McCoy, R., Wilson, E., and Mullen, J. (2005). A randomized, doubleblind, placebo-controlled trial of quetiapine in the treatment of bipolar I or II depression. Am. J. Psychiatry 162, 1351-1360.

Carr, D. B., Cooper, D. C., Ulrich, S. L., Spruston, N., and Surmeier, D. J. (2002). Serotonin receptor activation inhibits sodium current and dendritic excitability in prefrontal cortex via a protein kinase Cdependent mechanism. J. Neurosci. 22, 6846-6855.

Chalecka-Franaszek, E., and Chuang, D. M. (1999). Lithium activates the serine/threonine kinase Akt-1 and suppresses glutamate-induced inhibition of Akt-1 activity in neurons. Proc. Natl. Acad. Sci. U.S.A. 96, 8745-8750.

Chen, L., Salinas, G. D., and Li, X. (2009). Regulation of serotonin $1 \mathrm{~B}$ receptor by glycogen synthase kinase-3. Mol. Pharmacol. 76, 1150-1161.

Chen, L., Zhou, W., Chen, P., Gaisina, I., Yang, S., and Li, X. (2011). Glycogen synthase kinase-3beta is a functional modulator of serotonin $1 \mathrm{~b}$ receptors. Mol. Pharmacol. 79, 974-986.

Chen, S., Owens, G. C., Crossin, K. L., and Edelman, D. B. (2007). Serotonin stimulates mitochondrial transport in hippocampal neurons. Mol. Cell. Neurosci. 36, 472-483.

Chenu, F., David, D. J., Leroux-Nicollet, I., Le Maitre, E., Gardier, A. M., and Bourin, M. (2008). Serotonin1B heteroreceptor activation induces an antidepressant-like effect in mice with an alteration of the serotonergic system. J. Psychiatry Neurosci.33, 541-550.

Conn, P. J., and Sanders-Bush, E. (1984). Selective 5HT-2 antagonists inhibit serotonin stimulated phosphatidylinositol metabolism in cerebral cortex. Neuropharmacology 23, 993-996.

Cornea-Hebert, V., Riad, M., Wu, C., Singh, S. K., and Descarries, L. (1999). Cellular and subcellular distribution of the serotonin 5-HT2A receptor in the central nervous system of adult rat. J. Comp. Neurol. 409, 187-209.

Cowen, D. S., Johnson-Farley, N. N., and Travkina, T. (2005). 5-HT receptors couple to activation of Akt, but not extracellular-regulated kinase (ERK), in cultured hippocampal neurons. J. Neurochem. 93, 910-917.

Cowen, D. S., Sowers, R. S., and Manning, D. R. (1996). Activation of a mitogen-activated protein kinase (ERK2) by the 5hydroxytryptaminelA receptor is sensitive not only to inhibitors of phosphatidylinositol 3-kinase, but to an inhibitor of phosphatidylcholine hydrolysis. J. Biol. Chem. 271, 22297-22300.

Cross, D. A., Alessi, D. R., Cohen, P., Andjelkovich, M., and Hemmings, B. A. (1995). Inhibition of glycogen synthase kinase- 3 by insulin mediated by protein kinase B. Nature 378 , 785-789.

Dawson, L. A., Hughes, Z. A., Starr, K. R., Storey, J. D., Bettelini, L., Bacchi, F., Arban, R., Poffe, A., Melotto, S., Hagan, J. J., and Price, G. W. (2006). Characterisation of the selective 5-HT1B receptor antagonist SB-616234-A (1-[6-(cis3,5-dimethylpiperazin-1-yl)-2,3dihydro-5-methoxyindol-1-yl]-1[2'-methyl-4' - (5-methyl-1,2,4oxadiazol-3-yl)biphenyl-4yl]methanone hydrochloride): in vivo neurochemical and behavioural evidence of anxiolytic/antidepressant activity. Neuropharmacology 50, 975-983.

De Sarno, P., Li, X., and Jope, R. S. (2002). Regulation of Akt and glycogen synthase kinase- 3 beta phosphorylation by sodium valproate and lithium. Neuropharmacology 43, 1158-1164.

De Vivo, M., and Maayani, S. (1986). Characterization of the 5-hydroxytryptaminela receptor-mediated inhibition of forskolin-stimulated adenylate cyclase activity in guinea pig and rat hippocampal membranes. J. Pharmacol. Exp. Ther. 238, 248-253. 
Derry, S., and Moore, R. A. (2007). Atypical antipsychotics in bipolar disorder: systematic review of randomised trials. BMC Psychiatry 7, 40. doi:10.1186/1471-244X-7-40

DeWire, S. M., Ahn, S., Lefkowitz, R. J., and Shenoy, S. K. (2007). Betaarrestins and cell signaling. Annu. Rev. Physiol. 69, 483-510.

Di Giovanni, G., Di Matteo, V., Pierucci, M., and Esposito, E. (2008). Serotonin-dopamine interaction: electrophysiological evidence. Prog. Brain Res. 172, 45-71.

Doble, B. W., and Woodgett, J. R. (2003). GSK-3: tricks of the trade for a multi-tasking kinase. J. Cell. Sci. 116, 1175-1186.

Druse, M., Tajuddin, N. F., Gillespie, R. A., and Le, P. (2005). Signaling pathways involved with serotonin1A agonist-mediated neuroprotection against ethanol-induced apoptosis of fetal rhombencephalic neurons. Brain Res. Dev. Brain Res. 159, 18-28.

Du, J., Wei, Y., Liu, L., Wang, Y., Khairova, R., Blumenthal, R., Tragon, T., Hunsberger, J. G., Machado-Vieira, R., Drevets, W., Wang, Y. T., and Manji, H. K. (2010). A kinesin signaling complex mediates the ability of GSK-3beta to affect mood-associated behaviors. Proc. Natl. Acad. Sci. U.S.A. 107, 11573-11578.

Edagawa, Y., Saito, H., and Abe, K. (1998). 5-HT1A receptor-mediated inhibition of long-term potentiation in rat visual cortex. Eur. J. Pharmacol. 349, 221-224.

Esposito, E., Di Matteo, V., and Di Giovanni, G. (2008). Serotonindopamine interaction: an overview. Prog. Brain Res. 172, 3-6.

Fang, X., Yu, S. X., Lu, Y., Bast, R. C. Jr., Woodgett, J. R., and Mills, G. B. (2000). Phosphorylation and inactivation of glycogen synthase kinase 3 by protein kinase A. Proc. Natl. Acad. Sci. U.S.A. 97, 11960-11965.

Fink, K. B., and Gothert, M. (2007). 5-HT receptor regulation of neurotransmitter release. Pharmacol. Rev. 59, 360-417.

Gainetdinov, R. R., Premont, R. T., Bohn, L. M., Lefkowitz, R. J., and Caron, M. G. (2004). Desensitization of $\mathrm{G}$ protein-coupled receptors and neuronal functions. Annu. Rev. Neurosci. 27, 107-144.

Gaisina, I. N., Gallier, F., Ougolkov, A. V., Kim, K. H., Kurome, T., Guo, S., Holzle, D., Luchini, D. N., Blond, S. Y., Billadeau, D. D., and Kozikowski, A. P. (2009). From a natural product lead to the identification of potent and selective benzofuran-3yl-(indol-3-yl)maleimides as glycogen synthase kinase 3beta inhibitors that suppress proliferation and survival of pancreatic cancer cells. $J$. Med. Chem. 52, 1853-1863.

Gelber, E. I., Kroeze, W. K., Willins, D. L., Gray, J. A., Sinar, C. A., Hyde, E. G., Gurevich, V., Benovic, J., and Roth, B. L. (1999). Structure and function of the third intracellular loop of the 5hydroxytryptamine $2 \mathrm{~A}$ receptor: the third intracellular loop is alphahelical and binds purified arrestins. J. Neurochem. 72, 2206-2214.

Ghavami, A., Baruscotti, M., Robinson, R. B., and Hen, R. (1997). Adenovirus-mediated expression of 5 -HT1B receptors in cardiac ventricle myocytes; coupling to inwardly rectifying K+ channels. Eur. J. Pharmacol. 340, 259-266.

Goode, N., Hughes, K., Woodgett, J. R., and Parker, P. J. (1992). Differential regulation of glycogen synthase kinase- 3 beta by protein kinase C isotypes. J. Biol. Chem. 267, 16878-16882.

Gould, T. D., Einat, H., Bhat, R., and Manji, H. K. (2004). AR-A014418, a selective GSK-3 inhibitor, produces antidepressant-like effects in the forced swim test. Int. J. Neuropsychopharmacol. 7, 387-390.

Hannon, J., and Hoyer, D. (2008). Molecular biology of 5-HT receptors. Behav. Brain Res. 195, 198-213.

Hooper, C., Markevich, V., Plattner, F., Killick, R., Schofield, E., Engel, T., Hernandez, F., Anderton, B., Rosenblum, K., Bliss, T., Cooke, S. F., Avila, J., Lucas, J. J., Giese, K. P., Stephenson, J., and Lovestone, S. (2007). Glycogen synthase kinase-3 inhibition is integral to long-term potentiation. Eur. J. Neurosci. 25, 81-86.

Hoyer, D., Hannon, J. P., and Martin, G. R. (2002). Molecular, pharmacological and functional diversity of 5HT receptors. Pharmacol. Biochem. Behav. 71, 533-554.

Hoyer, D., and Martin, G. (1997). 5-HT receptor classification and nomenclature: towards a harmonization with the human genome. $\mathrm{Neu}$ ropharmacology 36, 419-428.

Hsiung, S. C., Tamir, H., Franke, T. F., and Liu, K. P. (2005). Roles of extracellular signal-regulated kinase and Akt signaling in coordinating nuclear transcription factorkappaB-dependent cell survival after serotonin 1A receptor activation. $J$. Neurochem. 95, 1653-1666.

Hsiung, S. C., Tin, A., Tamir, H., Franke, T. F., and Liu, K. P. (2008). Inhibition of 5-HT1A receptor-dependent cell survival by cAMP/protein kinase A: role of protein phosphatase $2 \mathrm{~A}$ and Bax. J. Neurosci. Res. 86, 2326-2338.

Jakab, R. L., and Goldman-Rakic, P. S. (1998). 5-Hydroxytryptamine2A serotonin receptors in the primate cerebral cortex: possible site of action of hallucinogenic and antipsychotic drugs in pyramidal cell apical dendrites. Proc. Natl. Acad. Sci. U.S.A. 95, 735-740.

Januel, D., Massot, O., Poirier, M. F., Olie, J. P., and Fillion, G. (2002). Interaction of lithium with 5$\mathrm{HT}(1 \mathrm{~B})$ receptors in depressed unipolar patients treated with clomipramine and lithium versus clomipramine and placebo: preliminary results. Psychiatry Res. 111 , 117-124.

Johnson-Farley, N. N., Kertesy, S. B., Dubyak, G. R., and Cowen, D. S. (2005). Enhanced activation of Akt and extracellular-regulated kinase pathways by simultaneous occupancy of Gq-coupled 5-HT2A receptors and Gs-coupled 5-HT7A receptors in PC12 cells. J. Neurochem. 92, 72-82.

Jope, R. S., and Johnson, G. V. W. (2004) The glamour and gloom of glycogen synthase kinase-3. Trends Biochem. Sci. 29, 95-102.

Kaidanovich-Beilin, O., Milman, A., Weizman, A., Pick, C. G., and Eldar-Finkelman, H. (2004). Rapid antidepressive-like activity of specific glycogen synthase kinase-3 inhibitor and its effect on betacatenin in mouse hippocampus. Biol. Psychiatry 55, 781-784.

Kapur, S., VanderSpek, S. C., Brownlee, B. A., and Nobrega, J. N. (2003). Antipsychotic dosing in preclinical models is often unrepresentative of the clinical condition: a suggested solution based on in vivo occupancy. J. Pharmacol. Exp. Ther. 305, 625-631.

Kennett, G. A., Dourish, C. T., and Curzon, G. (1987). Antidepressantlike action of 5-HT1A agonists and conventional antidepressants in an animal model of depression. Eur. J. Pharmacol. 134, 265-274.

Kim, J. J., and Jung, M. W. (2006). Neural circuits and mechanisms involved in Pavlovian fear conditioning: a critical review. Neurosci. Biobehav. Rev. 30, 188-202.

Klein, P. S., and Melton, D. A. (1996). A molecular mechanism for the effect of lithium on development. Proc. Natl. Acad. Sci. U.S.A. 93, 8455-8459.

Klerman, G. L., and Cole, J. O. (1965). Clinical pharmacology of imipramine and related antidepressant compounds. Pharmacol. Rev. 17, 101-141.

Kozlovsky, N., Amar, S., Belmaker, R. H., and Agam, G. (2006). Psychotropic drugs affect Ser9-phosphorylated GSK-3beta protein levels in rodent frontal cortex. Int. J. Neuropsychopharmacol. 9, 337-342.
Landolt, H. P., and Wehrle, R. (2009). Antagonism of serotonergic 5-HT2A/2C receptors: mutual improvement of sleep, cognition and mood? Eur. J. Neurosci. 29, 1795-1809.

Lefkowitz, R. J., and Shenoy, S. K. (2005). Transduction of receptor signals by beta-arrestins. Science 308 , 512-517.

Leone, A. M., Errico, M., Lin, S. L., and Cowen, D. S. (2000). Activation of extracellular signal-regulated kinase (ERK) and Akt by human serotonin 5-HT(1B) receptors in transfected $\mathrm{BE}(2)-\mathrm{C}$ neuroblastoma cells is inhibited by RGS4. J. Neurochem. 75, 934-938.

Leonardo, E. D., and Hen, R. (2008). Anxiety as a developmental disorder. Neuropsychopharmacology 33, 134-140.

Li, M., Wang, X., Meintzer, M. K., Laessig, T., Birnbaum, M. J., and Heidenreich, K. A. (2000). Cyclic AMP promotes neuronal survival by phosphorylation of glycogen synthase kinase 3beta. Mol. Cell. Biol. 20, 9356-9363.

Li, X., and Jope, R. S. (2010). Is glycogen synthase kinase-3 a central modulator in mood regulation? Neuropsychopharmacology 35, 2143-2154.

Li, X., Rosborough, K. M., Friedman, A. B., Zhu, W., and Roth, K. A. (2007). Regulation of mouse brain glycogen synthase kinase-3 by atypical antipsychotics. Int J. Neuropsychopharmacol. 10, 7-19.

Li, X., Zhu, W., Roh, M. S., Friedman, A. B., Rosborough, K., and Jope, R. S. (2004). In vivo regulation of glycogen synthase kinase-3beta (GSK3beta) by serotonergic activity in mouse brain. Neuropsychopharmacology 29, 1426-1431.

Liang, M. H., and Chuang, D. M. (2006). Differential roles of glycogen synthase kinase- 3 isoforms in the regulation of transcriptional activation. J. Biol. Chem. 281, 30479-30484.

Marcus, R. N., McQuade, R. D., Carson, W. H., Hennicken, D., Fava, M., Simon, J. S., Trivedi, M. H., Thase, M. E., and Berman, R. M. (2008). The efficacy and safety of aripiprazole as adjunctive therapy in major depressive disorder: a second multicenter, randomized, double-blind, placebo-controlled study. J. Clin. Psychopharmacol. 28, 156-165.

Marek, G. J., Carpenter, L. L., McDougle, C. J., and Price, L. H. (2003). Synergistic action of 5-HT2A antagonists and selective serotonin reuptake inhibitors in neuropsychiatric disorders. Neuropsychopharmacology 28, 402-412. 
Markowitz, J. S., Brown, C. S., and Moore, T. R. (1999). Atypical antipsychotics. Part I: Pharmacology, pharmacokinetics, and efficacy. Ann. Pharmacother. 33, 73-85.

Massot, O., Rousselle, J. C., Fillion, M. P., Januel, D., Plantefol, M., and Fillion, G. (1999). 5-HT1B receptors: a novel target for lithium. Possible involvement in mood disorders. Neuropsychopharmacology 21, 530-541.

McManus, E. J., Sakamoto, K., Armit, L. J., Ronaldson, L., Shpiro, N., Marquez, R., and Alessi, D. R. (2005). Role that phosphorylation of GSK3 plays in insulin and Wnt signalling defined by knockin analysis. $E M B O$ J. 24, 1571-1583.

Meltzer, H. Y., Matsubara, S., and Lee, J. C. (1989). The ratios of serotonin2 and dopamine 2 affinities differentiate atypical and typical antipsychotic drugs. Psychopharmacol. Bull. 25, 390-392.

Miner, L. A., Backstrom, J. R., SandersBush, E., and Sesack, S. R. (2003). Ultrastructural localization of serotonin $2 \mathrm{~A}$ receptors in the middle layers of the rat prelimbic prefrontal cortex. Neuroscience 116, 107-117.

New, D. C., Wu, K., Kwok, A. W., and Wong, Y. H. (2007). G proteincoupled receptor-induced Akt activity in cellular proliferation and apoptosis. FEBS J. 274, 6025-6036.

Nichols, D. E. (2004). Hallucinogens. Pharmacol. Ther. 101, 131-181.

O'Brien, W. T., Harper, A. D., Jove, F., Woodgett, J. R., Maretto, S., Piccolo, S., and Klein, P. S. (2004). Glycogen synthase kinase-3beta haploinsufficiency mimics the behavioral and molecular effects of lithium. $J$. Neurosci. 24, 6791-6798.

Ogren, S. O., Eriksson, T. M., ElvanderTottie, E., D’Addario, C., Ekstrom, J. C., Svenningsson, P., Meister, B., Kehr, J., and Stiedl, O. (2008). The role of 5-HT(1A) receptors in learning and memory. Behav. Brain Res. 195, 54-77.

Okamoto, H., Voleti, B., Banasr, M., Sarhan, M., Duric, V., Girgenti, M. J., Dileone, R. J., Newton, S. S., and Duman, R. S. (2010). Wnt2 expression and signaling is increased by different classes of antidepressant treatments. Biol. Psychiatry 68, 521-527.

Page, M. E., Detke, M. J., Dalvi, A., Kirby, L. G., and Lucki, I. (1999). Serotonergic mediation of the effects of fluoxetine, but not desipramine, in the rat forced swimming test. Psychopharmacology (Berl.) 147, 162-167.

Parks, C. L., Robinson, P. S., Sibille, E., Shenk, T., and Toth, M. (1998). Increased anxiety of mice lacking the serotonin1A receptor. Proc. Natl. Acad. Sci. U.S.A. 95, 10734-10739.

Peineau, S., Taghibiglou, C., Bradley, C., Wong, T. P., Liu, L., Lu, J., Lo, E., Wu, D., Saule, E., Bouschet, T., Matthews, P., Isaac, J. T., Bortolotto, Z. A., Wang, Y. T., and Collingridge, G. L. (2007). LTP inhibits LTD in the hippocampus via regulation of GSK3beta. Neuron 53, 703-717.

Perez-Costas, E., Gandy, J. C., MelendezFerro, M., Roberts, R. C., and Bijur, G. N. (2010). Light and electron microscopy study of glycogen synthase kinase-3beta in the mouse brain. PLoS ONE 5, e8911. doi:10.1371/journal.pone.0008911

Philip, N. S., Carpenter, L. L., Tyrka, A. R., and Price, L. H. (2008). Augmentation of antidepressants with atypical antipsychotics: a review of the current literature. J. Psychiatr. Pract. 14, 34-44.

Polter, A., Yang, S., Zmijewska, A. A., van Groen, T., Paik, J. H., Depinho, R. A., Peng, S. L., Jope, R. S., and Li, X. (2009). Forkhead box, class o transcription factors in brain: regulation and behavioral manifestation. Biol. Psychiatry 65, 150-159.

Polter, A. M., and Li, X. (2010). 5-HT1A receptor-regulated signal transduction pathways in brain. Cell Signaling 22, 1406-1412.

Polter, A. M., Beurel, E., Yang, S., Garner, R., Song, L., Miller, C. A., Sweatt, J. D., McMahon, L., Bartolucci, A. A., Li, X., and Jope, R. S. (2010). Deficiency in the inhibitory serinephosphorylation of glycogen synthase kinase-3 increases sensitivity to mood disturbances. Neuropsychopharmacology 35, 1761-1774.

Polter, A. M., Yang, S., Jope, R. S., and $\mathrm{Li}, \mathrm{X}$. (2011). Functional significance of glycogen synthase kinase- 3 regulation by serotonin. Cell Signal. doi: 10.1016/j.cellsig.2011.09.009. [Epub ahead of print].

Porsolt, R. D., Le Pichon, M., and Jalfre, M. (1977). Depression: a new animal model sensitive to antidepressant treatments. Nature 266, 730-732.

Price, J. L., and Drevets, W. C. (2010). Neurocircuitry of mood disorders. Neuropsychopharmacology 35, 192-216.

Ramboz, S, Oosting, R, Amara, D. A., Kung, H. F., Blier, P., Mendelsohn, M., Mann, J. J., Brunner, D., and Hen, R. (1998). Serotonin receptor 1A knockout: an animal model of anxiety-related disorder. Proc. Nat. Acad. Sci. USA 95, 14476-14481.

Redrobe, J. P., and Bourin, M. (1999). Evidence of the activity of lithium on 5-HT1B receptors in the mouse forced swimming test: comparison with carbamazepine and sodium valproate. Psychopharmacology (Berl.) 141, 370-377.

Riad, M., Garcia, S., Watkins, K. C., Jodoin, N., Doucet, E., Langlois, X., Mestikawy, S., Hamon, M., and Descarries, L. (2000). Somatodendritic localization of 5-HT1A and preterminal axonal localization of 5HT1B serotonin receptors in adult rat brain. J. Comp. Neurol. 417, 181-194.

Ritter, S. L., and Hall, R. A. (2009). Finetuning of GPCR activity by receptorinteracting proteins. Nat. Rev. Mol. Cell Biol. 10, 819-830.

Roh, M. S., Seo, M. S., Kim, Y., Kim, S. H., Jeon, W. J., Ahn, Y. M., Kang, U. G., Juhnn, Y. S., and Kim, Y. S. (2007). Haloperidol and clozapine differentially regulate signals upstream of glycogen synthase kinase 3 in the rat frontal cortex. Exp. Mol. Med. 39, 353-360.

Rosa, A. O., Kaster, M. P., Binfare, R. W., Morales, S., MartinAparicio, E., Navarro-Rico, M. L., Martinez, A., Medina, M., García, A. G., López, M. G., and Rodrigues, A. L. (2008). Antidepressant-like effect of the novel thiadiazolidinone NP031115 in mice. Prog. Neuropsychopharmacol. Biol. Psychiatry 32, 1549-1556.

Roth, B. L., Nakaki, T., Chuang, D. M., and Costa, E. (1986). 5Hydroxytryptamine 2 receptors coupled to phospholipase $\mathrm{C}$ in rat aorta: modulation of phosphoinositide turnover by phorbol ester. J. Pharmacol. Exp. Ther. 238, 480-485.

Sari, Y. (2004). Serotonin1B receptors: from protein to physiological function and behavior. Neurosci. Biobehav. Rev. 28, 565-582.

Savitz, J., Lucki, I., and Drevets, W. C. (2009). 5-HT(1A) receptor function in major depressive disorder. Prog. Neurobiol. 88, 17-31.

Schmid, C. L., and Bohn, L. M. (2010). Serotonin, but not Nmethyltryptamines, activates the serotonin $2 \mathrm{~A}$ receptor via a ssarrestin2/Src/Akt signaling complex in vivo. J. Neurosci. 30, 13513-13524.

Schmid, C. L., Raehal, K. M., and Bohn, L. M. (2008). Agonist-directed signaling of the serotonin $2 \mathrm{~A}$ receptor depends on beta-arrestin-2 interactions in vivo. Proc. Natl. Acad. Sci. U.S.A. 105, 1079-1084.

Schmidt, C. J., and Fadayel, G. M. (1995). The selective 5HT2A receptor antagonist, MDL 100,907, increases dopamine efflux in the prefrontal cortex of the rat. Eur. J. Pharmacol. 273, 273-279.

Schotte, A., Bonaventure, P., Janssen, P. F., and Leysen, J. E. (1995). In vitro receptor binding and in vivo receptor occupancy in rat and guinea pig brain: risperidone compared with antipsychotics hitherto used. Jpn. J. Pharmacol. 69, 399-412.

Stiedl, O., Misane, I., Spiess, J., and Ogren, S. O. (2000). Involvement of the 5-HT1A receptors in classical fear conditioning in C57BL/6J mice. J. Neurosci. 20, 8515-8527.

Svenningsson, P., Chergui, K., Rachleff, I., Flajolet, M., Zhang, X., El Yacoubi, M., Vaugeois, J. M., Nomikos, G. G., and Greengard, P. (2006). Alterations in 5-HT1B receptor function by $\mathrm{p} 11$ in depression-like states. Science 311, 77-80.

Svenningsson, P., and Greengard, P. (2007). p11 (S100A10) - an inducible adaptor protein that modulates neuronal functions. Curr. Opin. Pharmacol. 7, 27-32.

Tachibana, K., Matsumoto, M., Togashi, H., Kojima, T., Morimoto, Y., Kemmotsu, O., and Yoshioka, M. (2004). Milnacipran, a serotonin and noradrenaline reuptake inhibitor, suppresses long-term potentiation in the rat hippocampal CA1 field via 5-HT1A receptors and alpha 1 adrenoceptors. Neurosci. Lett. 357, 91-94.

Takuwa, N., Ganz, M., Takuwa, Y., Sterzel, R. B., and Rasmussen, H. (1989). Studies of the mitogenic effect of serotonin in rat renal mesangial cells. Am. J. Physiol. 257, F431-F439.

Talbot, J. N., Jutkiewicz, E. M., Graves, S. M., Clemans, C. F., Nicol, M. R., Mortensen, R. M., Huang, X., Neubig, R. R., and Traynor, J. R. (2010) RGS inhibition at G(alpha)i2 selectively potentiates 5-HT1A-mediated antidepressant effects. Proc. Natl. Acad. Sci. U.S.A. 107, 11086-11091.

Tobin, A. B. (2008). G-protein-coupled receptor phosphorylation: where, when and by whom. Br. J. Pharmacol. 153(Suppl. 1), S167-S176.

Tohen, M., Vieta, E., Calabrese, J., Ketter, T. A., Sachs, G., Bowden, C., Mitchell, P. B., Centorrino, F., Risser, R., Baker, R. W., Evans, A. R., Beymer, K. Dube, S., Tollefson, G. D., and Breier, A. (2003). Efficacy of olanzapine and olanzapine-fluoxetine combination in the treatment of bipolar I depression. Arch. Gen. Psychiatry 60, 1079-1088.

Trillat, A. C., Malagie, I., Scearce, K., Pons, D., Anmella, M. C., Jacquot, C., Hen, R., and Gardier, A. M. (1997). Regulation of serotonin release in the frontal cortex and ventral hippocampus of homozygous mice lacking 5-HT1B receptors: in vivo microdialysis studies. J. Neurochem. 69, 2019-2025. 
Tsetsenis, T., Ma, X. H., Lo Iacono, L., Beck, S. G., and Gross, C. (2007). Suppression of conditioning to ambiguous cues by pharmacogenetic inhibition of the dentate gyrus. Nat. Neurosci. 10, 896-902.

Varnas, K., Halldin, C., and Hall, H. (2004). Autoradiographic distribution of serotonin transporters and receptor subtypes in human brain. Hum. Brain Mapp. 22, 246-260.

Wang, Q. M., Park, I. K., Fiol, C. J., Roach, P. J., and DePaoli-Roach, A. A. (1994). Isoform differences in substrate recognition by glycogen synthase kinases 3 alpha and 3 beta in the phosphorylation of phosphatase inhibitor 2. Biochemistry 33, 143-147.

Watts, S. W. (1998). Activation of the mitogen-activated protein kinase pathway via the 5-HT2A receptor. Ann. N. Y. Acad. Sci. 861, 162-168.

Weiner, D. M., Burstein, E. S., Nash, N., Croston, G. E., Currier, E. A., Vanover, K. E., Harvey, S. C., Donohue, E., Hansen, H. C., Andersson, C. M., Spalding, T. A.,
Gibson, D. F., Krebs-Thomson, K., Powell, S. B., Geyer, M. A., Hacksell, U., and Brann, M. R. (2001). 5-hydroxytryptamine $2 \mathrm{~A}$ receptor inverse agonists as antipsychotics. J. Pharmacol. Exp. Ther. 299, 268-276. Woodgett, J. R. (2001). Judging a protein by more than its name: GSK-3. Sci. STKE 2001, RE12.

Yan, W., Wilson, C. C., and Haring, J. H. (1997). 5-HT1a receptors mediate the neurotrophic effect of serotonin on developing dentate granule cells. Brain Res. Dev. Brain Res. 98, 185-190.

Yang, M., He, R. L., Benovic, J. L., and Ye, R. D. (2009). beta-Arrestin 1 interacts with the G-protein subunits betalgamma2 and promotes betalgamma2-dependent Akt signalling for NF-kappaB activation. Biochem. J. 417, 287-296.

Youdim, M. B., and Bakhle, Y. S. (2006). Monoamine oxidase: isoforms and inhibitors in Parkinson's disease and depressive illness. Br. J. Pharmacol. 147(Suppl. 1), S287-S296.

Yuan, Q., Lin, F., Zheng, X., and Sehgal, A. (2005). Serotonin modulates circadian entrainment in Drosophila. Neuron 47, 115-127.

Yuen, E. Y., Jiang, Q., Chen, P., Feng, J., and Yan, Z. (2008). Activation of 5-HT2A/C receptors counteracts 5 -HT1A regulation of $\mathrm{N}$ methyl-D-aspartate receptor channels in pyramidal neurons of prefrontal cortex. J. Biol. Chem. 283, 17194-17204.

Zhang, W., Perry, K. W., Wong, D. T., Potts, B. D., Bao, J., Tollefson, G. D., and Bymaster, F. P. (2000) Synergistic effects of olanzapine and other antipsychotic agents in combination with fluoxetine on norepinephrine and dopamine release in rat prefrontal cortex. Neuropsychopharmacology

23, 250-262.

Zhang, X., Gainetdinov, R. R., Beaulieu, J. M., Sotnikova, T. D., Burch, L. H., Williams, R. B., Schwartz, D. A., Krishnan, K. R., and Caron, M. G. (2005). Loss-offunction mutation in tryptophan hydroxylase-2 identified in unipolar major depression. Neuron 45, 11-16.
Zhong, P., Yuen, E. Y., and Yan, Z. (2008). Modulation of neuronal excitability by serotoninNMDA interactions in prefrontal cortex. Mol. Cell. Neurosci. 38, 290-299.

Conflict of Interest Statement: The authors declare that the research was conducted in the absence of any commercial or financial relationships that could be construed as a potential conflict of interest.

Received: 26 July 2011; accepted: 28 September 2011; published online: 24 October 2011.

Citation: Polter AM and Li X (2011) Glycogen synthase kinase-3 is an intermediate modulator of serotonin neurotransmission. Front. Mol. Neurosci. 4:31. doi: 10.3389/fnmol.2011.00031

Copyright (c) 2011 Polter and Li. This is an open-access article subject to a nonexclusive license between the authors and Frontiers Media SA, which permits use, distribution and reproduction in other forums, provided the original authors and source are credited and other Frontiers conditions are complied with. 